\title{
Dissolution of Stone Wool Fibers with Phenol-urea-formaldehyde Binder in a Synthetic Lung Fluid
}

Barly, Susanne H.Q.; Okhrimenko, Denis V.; Solvang, Mette; Yue, Yuanzheng; Stipp, Susan L.S.

Published in:

Chemical Research in Toxicology

Link to article, DOI:

10.1021/acs.chemrestox.9b00179

Publication date:

2019

Document Version

Publisher's PDF, also known as Version of record

Link back to DTU Orbit

Citation (APA):

Barly, S. H. Q., Okhrimenko, D. V., Solvang, M., Yue, Y., \& Stipp, S. L. S. (2019). Dissolution of Stone Wool Fibers with Phenol-urea-formaldehyde Binder in a Synthetic Lung Fluid. Chemical Research in Toxicology, 32(12), 2398-2410. https://doi.org/10.1021/acs.chemrestox.9b00179

\section{General rights}

Copyright and moral rights for the publications made accessible in the public portal are retained by the authors and/or other copyright owners and it is a condition of accessing publications that users recognise and abide by the legal requirements associated with these rights.

- Users may download and print one copy of any publication from the public portal for the purpose of private study or research.

- You may not further distribute the material or use it for any profit-making activity or commercial gain

- You may freely distribute the URL identifying the publication in the public portal 


\title{
Dissolution of Stone Wool Fibers with Phenol-urea-formaldehyde Binder in a Synthetic Lung Fluid
}

\author{
Susanne H. Q. Barly, ${ }^{\dagger}$ Denis V. Okhrimenko, ${ }^{* \dagger \odot}$ Mette Solvang, ${ }^{\dagger}$ Yuanzheng Yue, ${ }^{\ddagger}$ \\ and Susan L. S. Stipp ${ }^{\S}$ \\ ${ }^{\dagger}$ ROCKWOOL International A/S, Hovedgaden 584, 2640 Hedehusene, Denmark \\ ${ }^{\ddagger}$ Department of Chemistry and Bioscience, Aalborg University, 9220 Aalborg, Denmark \\ ${ }^{\S}$ Department of Physics, Technical University of Denmark, 2800 Kongens Lyngby, Denmark
}

Supporting Information

\begin{abstract}
Mineral wool products, composed of stone wool fibers and organic binder, are used in many construction applications. Among all their beneficial properties, the most important requirement is safety for human health, such as when fibers are inhaled. For determining long-term toxicity, biosolubility and biopersistence studies in vitro and in vivo are essential. In vitro fiber dissolution rate, which depends on the medium, fiber composition, and the surface available for dissolution, is a key parameter in determining biopersistence of the material in vivo. We investigated how organic binder (phenol-ureaformaldehyde), which can partially shield fiber surfaces from the solution, influences fiber dissolution kinetics in synthetic lung fluid (modified Gamble's solution) at $\mathrm{pH} 4.5$ and temperature $37{ }^{\circ} \mathrm{C}$, in vitro. Dissolution experiments were made in batch and continuous flow using stone wool fibers with typical insulation product binder amounts (0-6 wt \%), applied by the standard industrial process. Dissolution rates were determined from element concentrations in the reacted solution, and changes in fiber surface composition and morphology were monitored. Stone wool fiber dissolution was close to stoichiometric and was similar, whether or not the material contained binder. The high dissolution rate $\left(508 \mathrm{ng}\right.$ of fiber $\left./ \mathrm{cm}^{2} / \mathrm{h}\right)$ is explained by Al and Fe complexing agents, that is, citrate and tartrate, in the synthetic lung fluid. The organic binder mainly forms micrometersized discrete droplets on the fiber surfaces rather than a homogeneous thick coating. During in vitro tests, fibers with organic binder preferentially dissolved in the areas free of binder, forming cavities, whereas the untreated fibers dissolved homogeneously. Propagation of cavities undermined the binder droplets, leading to complete fiber dissolution. Thus, presence of organic binder on stone wool fibers, produced by the standard industrial process, had no measurable effect on dissolution rate in synthetic lung fluid containing $\mathrm{Al}$ and $\mathrm{Fe}$ complexing agents.
\end{abstract}

\section{INTRODUCTION}

Mineral wool insulation products have been a cornerstone in many areas of the construction sector for several decades. The application of mineral wool insulation products ranges from thermal and acoustic insulation over façade materials to fire barriers. One group of mineral wool insulation products is called stone wool, which is typically produced from natural rock, that is, diabase, basalt, anorthosite, dolomite, olivine sand, and often residual materials from various industries. As for other mineral wool insulation products, stone wool consists of micrometer diameter fibers that have a characteristic amorphous glassy structure, which results from hyper quenching of the melt during manufacturing using external centrifugation. ${ }^{1,2}$ Typically, stone wool fibers have a geometric mean diameter of $2.5-4 \mu \mathrm{m}$ and a length up to $2 \mathrm{~mm}$. Finished stone wool products consist of inorganic fibers and shots (nonfiberized melt) as well as organic binder, which is often a phenol-urea-formaldehyde (PUF) thermosetting resin, ${ }^{3}$ that when cured joins the individual fibers, providing strength and the desired mechanical properties. An example of the final stone wool product is shown in Figure 1, where both the inorganic fibers and the organic binder can be seen.

Product quality and performance are important, but ensuring safety to humans and the environment is absolutely essential throughout the life cycle of the product. ${ }^{4,5}$ The typical exposure route for humans to mineral wool fibers is via inhalation. Inhalation is a potential risk if fibers become airborne during production, installation, or building demolition. A small portion of airborne fibers can reach the pulmonary region of the lungs. ${ }^{6}$ These, called respirable fibers, which are able to reach the alveoli, ${ }^{7}$ are defined to be $<3 \mu \mathrm{m}$ in diameter, $>5 \mu \mathrm{m}$ in length, and aspect ratio (length/diameter) of $>3 .{ }^{8}$ This fraction of fibers could, according to the 3D paradigm $^{1,9-11}$ of fiber toxicity (dose, dimension, and durability), pose a hazard if they are biopersistent, that is, if they remain in the lungs and are not adequately cleared. Stone wool fibers have demonstrated low biopersistence determined

Received: April 29, 2019

Published: November 4, 2019 


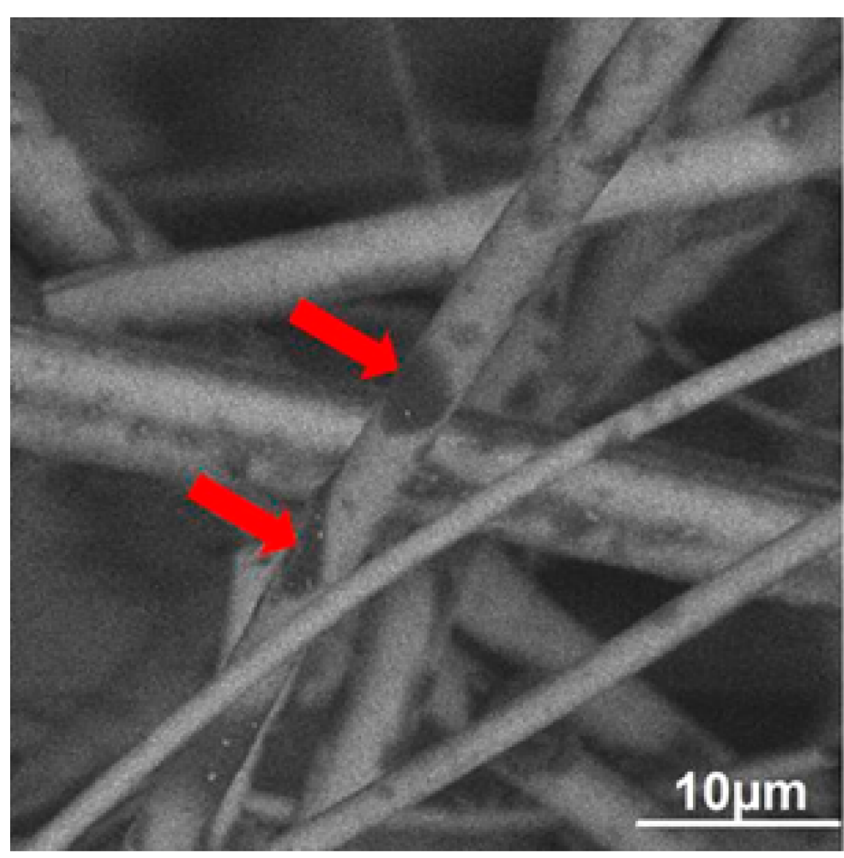

Figure 1. SEM image of a final stone wool product with 2.0 wt \% binder. Dark spots on the fiber surface indicated with red arrows are PUF binder.

using in vivo testing. ${ }^{12-18}$ Based on in vivo results, mineral wool fibers can be exonerated from classification as carcinogenic when fulfilling Note $Q$ defined by the European Commission in Regulation (EC) no. 1272/2008. For clearance in the lungs, both dissolution and breakdown of the fibers are the important factors. ${ }^{8,17}$ The respirable fibers including even thin and long fibers can potentially end up in the pulmonary region of the lungs. ${ }^{19,20}$ Respirable short fibers $(<20 \mu \mathrm{m})$ can be engulfed and mechanically cleared by macrophages and thus do not stimulate inflammatory mediators. ${ }^{19,20}$ In contrast, long fibers $(>20 \mu \mathrm{m})$ cannot be sufficiently phagocytosed and could potentially lead to frustrated phagocytosis or multiple phagocytosis events. ${ }^{20}$ However, the ability of the fiber to persist in the lung milieu defines whether a long fiber will stimulate inflammation or not.

Two primarily milieus exist in the lung and both can dissolve mineral wool fibers. Dissolution of the fibers can happen in two locations in the lungs: in the extracellular, lung airway surface liquid and in the intracellular macrophage phagolysosome. ${ }^{21}$ The $\mathrm{pH}$ of the lung air surface liquid and alveolar subphase fluid is close to neutral, between 6.6 and $7.1,{ }^{21}$ and the $\mathrm{pH}$ reported for macrophages is from 4.5 to 5.0. ${ }^{2,23}$ Therefore, fiber dissolution in the lung can, in a simplified way, be classified as extracellular, with the $\mathrm{pH}$ close to neutral, and intracellular dissolution by macrophages, where $\mathrm{pH}$ of the environment is more acidic. Hence, the dissolution rate depends upon fiber and milieu composition and $\mathrm{pH}$. Eastes et al. $^{17}$ showed in in vivo studies of two different mineral wool fibers (glass and stone wool) that long fibers can be cleared by at least two different dissolution mechanisms. For the extracellular milieu, the dissolution is uniform for the glass wool fiber, while for the intracellular milieu the stone wool fiber dissolves readily and thus the phagocyte attack breaks long fibers into shorter fragments that are readily cleared by macrophages physical action. ${ }^{17}$ Hence, the overall biopersistence of a long fiber depends on its biosolubility, breakage, macrophage phagocytosis, and mechanical clearance. ${ }^{20}$ Dissolution rates for glass ${ }^{24}$ and stone wool fibers depend on their chemical composition. ${ }^{7,18,25,26}$ They have been determined in many experiments, in vitro, acellularly, using flow through setups with different fluids resembling both lung airway surface liquid and the macrophage environment, ${ }^{27,28}$ as well as with cellular models using the various cell types present in lung fluid. $^{29-33}$ Correlations between results of in vivo and in vitro dissolution in the synthetic lung fluids have been reported and summarized for many fiber materials by Hesterberg et al.

To simulate lung fluid ${ }^{28,34,35}$ with in vitro dissolution tests, several modifications of Gamble's solution ${ }^{36}$ can be used to represent the interstitial liquid in the deep lung. Composition of the synthetic lung fluid influences stone wool fibers dissolution rate. ${ }^{28}$ To standardize the procedure for comparing biopersistence of several fiber types, ${ }^{37}$ it was recommended to use synthetic lung fluid composition based on Gamble's solution. ${ }^{38}$ Citrate and tartrate are added to the Gamble's solution to represent proteins present in the lung fluid, ${ }^{36,39-43}$ and they were found to be responsible for enhancing dissolution of stone wool fibers. ${ }^{44}$ Citrate and tartrate increase dissolution rate of stone wool fibers with high $\mathrm{Al} / \mathrm{Si}$ ratio because of $\mathrm{Al}$ complexing and depletion of $\mathrm{Al}$ from the fiber surface, similar to ligand promoted dissolution for feldspars ${ }^{45}$ and other aluminosilicates. ${ }^{46}$ However, ligand promoted dissolution of stone wool fibers is $\mathrm{pH}$ dependent, ${ }^{9}$ and dissolution rates decrease as $\mathrm{pH}$ increases. ${ }^{14}$ The macrophage phago-lysosome environment can also be simulated using alveolar lysosome fluid (ALF), ${ }^{47}$ but it contains a higher concentration of complexing agents (citric acid/citrate) so the dissolution conditions would be significantly more aggressive than with the modified Gamble's solution. This would probably have obscured the effects of the binder or other organics present on the fiber surfaces on the dissolution rate.

In many studies, ${ }^{13-18,25,28,44,48}$ because of scientific, regulatory and technical reasons, the dissolution was investigated for mineral wool fibers that had not been treated with organic binder. These studies helped to increase the understanding of health properties and associated mechanisms of such fibers. An additional layer of complexity was added to the scientific understanding of health properties of mineral wool fibers when several epidemiological studies were conducted, this time focusing on occupational exposure to industrially manufactured fibers, thus fibers with binder. After evaluation of all present studies (with and without binder) at that time, the comprehensive WHO Monograph 81 of the International Agency for Research on Cancer (IARC) ${ }^{8}$ concluded in 2002 that mineral wool fibers cannot be classified for carcinogenicity to humans. ${ }^{8,49}$ Recently, fibers with binder have been used within various in vitro dissolution assays under different scientific point of views. ${ }^{50-53}$

In this work, we investigated if and how the presence of the organic binder could influence the dissolution rate of stone wool fibers in synthetic lung fluid of standard composition ${ }^{38}$ at $37^{\circ} \mathrm{C}$ and $\mathrm{pH} 4.5$, which was intended to simulate intracellular dissolution by macrophages in human lungs. We compared the behavior of stone wool fibers with similar inorganic composition but with different amounts of binder, ranging from 0 to $6.4 \mathrm{wt} \%$. All fiber samples were produced by the ROCKWOOL Group, following the standard stone wool insulation production process. Inorganic fiber composition was chosen in accordance with Note $Q$ by the European Commission in Regulation (EC) no. 1272/2008. The amount 
of binder typical for finished stone wool products is $1-4$ wt \%, so the investigated amount ranged to a value higher than any that would be found associated with an airborne respirable fiber fraction.

We compared the results from static batch dissolution for 4 $\mathrm{d}$ and dynamic flow dissolution for $28 \mathrm{~d}$. Although static batch dissolution experiments are easier and the results often correlate with dynamic flow test results, ${ }^{54}$ the dissolution rate from batch experiments is influenced by increasing concentrations of the released elements as the system approaches saturation or equilibrium and by decrease in the concentration of free ligand. Fiber samples were analyzed with several techniques to characterize their composition (X-ray fluorescence), the binder content (thermogravimetry, TG, and loss on ignition, LOI), and surface area using fiber diameter distribution. Morphology change after dissolution was examined with scanning electron microscopy (SEM) and change in surface chemistry by X-ray photoelectron (XPS) and energy dispersive X-ray spectroscopies (EDXS). Dissolution rates were determined from solution concentrations using atomic absorption spectroscopy (AAS).

\section{EXPERIMENTAL PROCEDURES}

2.1. Stone Wool Fiber Production. Stone wool fibers with different amounts of PUF binder were produced at the ROCKWOOL A/S factory in Øster Doense, Denmark utilizing the traditionally melting unit; a cupola for the production of the stone wool melt. The amount of binder was chosen to obtain stone wool fiber material with binder content of $0 \%(\mathrm{~F} 1)$, 2.3\% (F2), 3.5\% (F3), and $6.4 \%(\mathrm{~F} 4)$ of the total sample mass. In addition to PUF binder, mineral oil ( $0.1 \%$ of the fiber material) and 3-aminopropylsilane (APS, $0.4 \%$ of binder content) were added simultaneously during fiber production. APS enhances adhesion of the PUF binder to the stone wool fibers, and oil is used to increase hydrophobicity of the final product and to reduce dust formation during production, handling, and installation. The combination of PUF binder, mineral oil, and APS is referred to as the binder or the organic material throughout the text, and PUF is the main constituent of this organic material. All stone wool fiber materials, including the material with $0 \%$ binder added, were cured at $230{ }^{\circ} \mathrm{C}$ in the curing oven in the factory production line. After curing, the stone wool products were collected, and cylindrical pieces were cut randomly in several places from the stone wool products. These pieces were sieved at $\leq 63 \mu \mathrm{m}$, to separate fibers from shots, the spherical particles that result from the stone wool fiber forming process when using the cascade spinning technology. About $30 \mathrm{~g}$ of sieved fiber samples (F1, F2, F3, and F4) were prepared, and subsamples were taken from them for all the experiments and analyses unless otherwise specified. The fresh fibers were characterized before experiments using X-ray fluorescence (XRF), X-ray photoelectron spectroscopy (XPS), and scanning electron microscopy coupled with energy dispersive X-ray spectroscopy (SEM-EDXS), and total organic content (TG and loss on ignition, LOI) and material surface area were determined. After dissolution experiments, the remaining fibers were examined with XPS and SEM-EDXS.

2.2. Organic Material Concentration. The amount of organic material in the stone wool samples, consisting of oil, APS, and PUF binder, was determined by measuring mass loss during heating to 600 ${ }^{\circ} \mathrm{C}$ under air flow using thermogravimetry (TG) (NETZSCH STA 449 F1 Jupiter). At this high temperature, the organic material degrades into gaseous phases and leaves the sample. Sieved samples $(10-20 \mathrm{mg})$ were heated in the platinum crucible at $20^{\circ} / \mathrm{min}$ and held at maximum temperature $\left(600^{\circ} \mathrm{C}\right)$ for $20 \mathrm{~min}$. Stone wool fibers are stable at that temperature and are not oxidized in air, ${ }^{55}$ so mass increase is not expected to be caused by oxidation during heating. We compared our results with results from a standard loss on ignition (LOI). In that analysis, $\sim 5 \mathrm{~g}$ of sample is heated in preannealed aluminum foil trays at $590{ }^{\circ} \mathrm{C}$.
2.3. Bulk Composition. Chemical composition of the fiber samples (F1, F2, F3, and F4) was determined using Thermo Scientific ARL Advant'X 2095 XRF IntelliPower. Samples were initially heated to $590{ }^{\circ} \mathrm{C}$ for $20 \mathrm{~min}$ to remove organic material and then ground in a ball mill. $0.75 \mathrm{~g}$ of the sample was mixed with $9.09 \mathrm{~g}$ of $\mathrm{Li}_{2} \mathrm{~B}_{4} \mathrm{O}_{7}$ and melted into a pellet with a Katanax X-300.

2.4. Fiber Diameter Distribution. The fiber sample diameter distribution was determined using SEM image analysis. Sieved samples that had been heated to remove the organic material were distributed on sample holders to avoid overlap. The length weighted diameter distribution was determined by measuring the diameter of fibers crossing a slice of the image. Fibers were identified as features with two parallel sides. For reasonable statistics, the number of fibers measured was at least 100 times the median diameter in $\mu \mathrm{m}$ in the sample. For example, if the median diameter was $5 \mu \mathrm{m}$, at least 500 fibers were measured. ${ }^{56,57}$

The diameter distribution is given in $d_{50}$, which is the median diameter. The specific surface area can be determined from the diameter distribution of each sample: ${ }^{58}$

$$
S=\frac{4}{\rho \times d_{50}} \times \exp \left(\frac{-3 \times s^{2}}{4}\right)
$$

where $S$ denotes the specific surface area, $\rho$ is the fiber density determined from chemical composition $\left(2.8 \mathrm{~g} / \mathrm{cm}^{3}\right), d_{50}$ is the $50 \%$ diameter distribution, and $s$ is the standard deviation $(s=1 / 2 \times \sqrt{2} \times$ $\ln \left(d_{84} / d_{16}\right)$, where $d_{84}$ and $d_{16}$ represent the 16 and $84 \%$ diameter distributions).

2.5. Synthetic Lung Fluid. Synthetic lung fluid for the fiber dissolution tests was prepared from salts of ACS purity grade and deionized water (specific conductivity of $0.1 \mu \mathrm{S} / \mathrm{cm}$ ), according to the composition reported in Sebastian et. al (Table 1). ${ }^{38}$ Glycine was

Table 1. Composition of the Synthetic Lung Fluid

\begin{tabular}{|c|c|c|}
\hline \multirow[b]{2}{*}{ compound } & \multicolumn{2}{|c|}{ concentration } \\
\hline & $\mathrm{g} / \mathrm{L}$ & $\mathrm{mmol} / \mathrm{L}$ \\
\hline $\mathrm{NaHCO}_{3}$ & 1.950 & 23.21 \\
\hline $\mathrm{NaCl}$ & 7.120 & 121.71 \\
\hline $\mathrm{MgCl}_{2} \cdot 6 \mathrm{H}_{2} \mathrm{O}$ & 0.212 & 1.05 \\
\hline $\mathrm{CaCl}_{2} \cdot 2 \mathrm{H}_{2} \mathrm{O}$ & 0.029 & 0.20 \\
\hline $\mathrm{Na}_{2} \mathrm{HPO}_{4}$ & 0.148 & 1.04 \\
\hline $\mathrm{Na}_{2} \mathrm{SO}_{4}$ & 0.079 & 0.56 \\
\hline Glycine & 0.118 & 1.57 \\
\hline $\mathrm{Na}_{3}$ citrate $\cdot 2 \mathrm{H}_{2} \mathrm{O}$ & 0.152 & 0.52 \\
\hline $\mathrm{Na}_{2}$ tartrate $\cdot 2 \mathrm{H}_{2} \mathrm{O}$ & 0.180 & 0.78 \\
\hline Na pyruvate & 0.172 & 1.56 \\
\hline lactic acid (90\%) & 0.156 & 1.56 \\
\hline formaldehyde & $2 \mathrm{~mL} / \mathrm{L}$ & 54.33 \\
\hline $\mathrm{HCl} 5 \mathrm{M}$ & $\sim 3.9 \mathrm{~mL} / \mathrm{L}$ & $\sim 19.5$ \\
\hline
\end{tabular}

PharmaGrade (Ajinomoto, EP, JP, USP, manufactured under appropriate GMP controls for pharma or biopharmaceutical production, suitable for cell culture), $\mathrm{Na}_{2}$ tartrate $2 \mathrm{H}_{2} \mathrm{O}$ was purchased from EMSURE (EMD Millipore), Na pyruvate from EMD Millipore, and lactic acid (90\%) was supplied by Sigma-Aldrich. Formaldehyde was added to discourage microbial growth, and $\mathrm{HCl}$ was added for $\mathrm{pH}$ control. The solutions were left to degas overnight, and $\mathrm{pH}$ was adjusted to $4.50 \pm 0.01$.

2.6. Dissolution Experiments. 2.6.1. Static Batch Dissolution. Dissolution of the stone wool fiber samples, with a range of binder (F1, F2, F3, and F4), in the synthetic lung fluid was investigated in batch experiments that lasted $4 \mathrm{~d}$. Samples were taken every $24 \mathrm{~h}$, and 3 repetitions of each sample were made. In all experiments, the fiber mass-to-solution volume ratio was $0.6 \mathrm{~g} / \mathrm{L}$, and the temperature was set to $37^{\circ} \mathrm{C}$. Samples were shaken, and $\mathrm{pH}$ was adjusted with $1 \mathrm{M}$ hydrochloric acid to $4.50 \pm 0.04$ once a day. The amount of added 1 $\mathrm{M} \mathrm{HCl}$ was $120-130 \mu \mathrm{L}$ per day for all samples. The material was 
passed through $8-13 \mu \mathrm{m}$ cellulose filters, and solution composition was determined with AAS. Using finer filters for this stage was not possible because of the filters blockage during filtration. No transmission of the fibers into the filtrate was observed. Fibers collected from the experiments were washed with $50 \mathrm{~mL}$ deionized water, dried at $37{ }^{\circ} \mathrm{C}$ overnight, and analyzed with SEM-EDXS and XPS.

2.6.2. Dynamic Flow Dissolution. The procedure for constant flow experiments was adopted from the work of Sebastian and colleagues. ${ }^{38}$ The temperature was set to $37{ }^{\circ} \mathrm{C}$. Temperature and $\mathrm{pH}$ of the input solution were monitored automatically (Orion Versa Star Pro $\mathrm{pH} / \mathrm{mV}$ benchtop meter, ROSS electrodes, Thermofisher 8107 UWMMD Triode) every $30 \mathrm{~min}$. Fluid flow rate was held constant at $123.5 \mathrm{~mL} / \mathrm{d}$ with a peristaltic pump (ISMATEC IPC ISM 930), and flow cells were equipped with magnetic stirrers (Figure 2). Teflon tubes connected the inlet and outlet to the pump and flow cells. To prevent fibers loss from the cell during flow, $0.22 \mu \mathrm{m}$ filters were used.

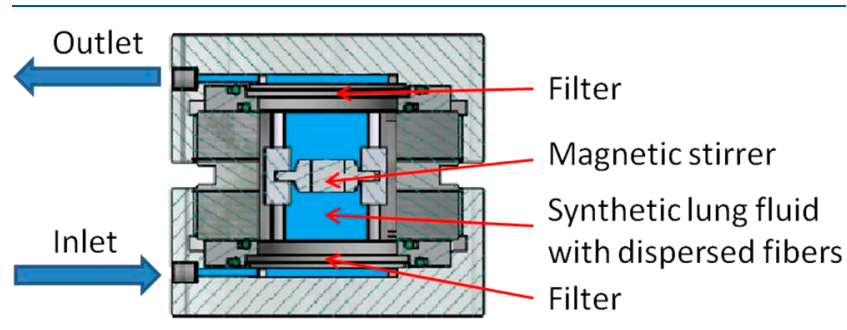

Figure 2. Schematic representation of the Plexiglas flow cell used for the dynamic flow dissolution experiments. The fluid volume in the cell is approximately $50 \mathrm{~mL}$.

The flow experiments were run without fiber materials for $2 \mathrm{~d}$ to verify that they functioned properly and no $\mathrm{pH}$ change occurred. Fibers were added to give a flow rate/surface area (F/A) of $0.03 \mu \mathrm{m} /$ s. Surface area had been determined for each of the fiber samples. We sampled the effluent after $1,2,3,4,7,11,14,21$, and $28 \mathrm{~d}$ and measured $\mathrm{pH}$ immediately after sampling. The solutions were analyzed with AAS. After $28 \mathrm{~d}$, the remaining fibers were collected, washed with $50 \mathrm{~mL}$ deionized water, dried overnight at $37^{\circ} \mathrm{C}$, and analyzed with SEM-EDXS and XPS.

2.7. Scanning Electron Microscopy with Energy-Dispersive $\mathrm{X}$-Ray Spectroscopy. The fiber samples from the static and dynamic flow tests were mounted on sample holders with double-sided conductive carbon tape and analyzed with SEM-EDXS using Tescan VEGA3 scanning electron microscope. They were carefully pressed onto the tape for better adhesion, and loose fibers were blown away with an air stream. After the SEM-EDXS analysis was complete, the samples were coated with gold for $180 \mathrm{~s}$ with a sputtering current of $30 \mathrm{~mA}$ for SEM imaging with secondary electrons (SE) for better topological contrast. Voltage of $30 \mathrm{kV}$ was used for the SEM images, at a minimum of 2 spots and with 3 magnifications (6890, 724, and 329 times). Low voltage ( $5 \mathrm{kV})$ was used for imaging with backscatter electrons (BSE), because fiber area covered with organic material is not visible under high voltage.
2.8. X-ray Photoelectron Spectroscopy. XPS experiments were made using a Kratos Axis Ultra ${ }^{\text {DLD }}$ system, with a monochromatic $\mathrm{Al}_{\mathrm{K} \alpha} \mathrm{X}$-ray source $(h \nu=1486.6 \mathrm{eV}$, power $=150 \mathrm{~W})$. The base pressure of the ultrahigh-vacuum (UHV) chamber was $5 \times 10^{-9}$ Torr. Pass energy of $160 \mathrm{eV}$ and step size of $0.3 \mathrm{eV}$ were used for survey spectra. For the high-resolution spectra for the $\mathrm{C} 1 \mathrm{~s}$ region, we used pass energy of $10 \mathrm{eV}$ and step size of $0.1 \mathrm{eV}$. The spectra were analyzed using the commercial software, CasaXPS. The resulting data were fit with Shirley background correction. All spectra were calibrated by assigning the characteristic adventitious carbon $\mathrm{C} 1 \mathrm{~s}$ peak energy to $285.0 \mathrm{eV}$. Samples were analyzed before and after dissolution.

2.9. Atomic Absorption Spectroscopy. We analyzed the solutions using a PerkinElmer PinAAcle 900F AAS, to quantify the concentrations of $\mathrm{Si}, \mathrm{Al}, \mathrm{Mg}, \mathrm{Ca}$, and $\mathrm{Fe}$. To prevent ionization during analysis, $\mathrm{KCl}$ was added.

\section{RESULTS}

3.1. Characterization of the Initial Fiber Materials: XRF, Density, TG, Loss on Ignition, Surface Area, XPS. Table 2 presents the bulk composition and other information about the samples. The bulk composition of the fiber samples is similar, within uncertainty. Small amounts $(<0.7 \mathrm{wt} \%$, not included to Table 2) of $\mathrm{TiO}_{2}, \mathrm{P}_{2} \mathrm{O}_{5}$, and $\mathrm{MnO}$ were found in all samples, in addition to main components. We did not specifically analyze for trace metals, but in XPS analysis, heavy metal concentration was below detection for fibers, both before or after dissolution, as expected. The trace metal concentration $(<0.15 \mathrm{wt} \%)$ of the source material for the fiber products is routinely, carefully monitored to be sure that the product meets the environmental legislation limits so trace metals during the dissolution experiments would likewise be very low. The chemical composition of stone wool fibers can significantly affect dissolution rate, ${ }^{18}$ so it was important for comparison of dissolution rate dependence on binder content that the four samples were chemically similar. The stoichiometric formula for the fibers, based on the XRF analysis and taking into account that the iron is present only as $\mathrm{Fe}(\mathrm{II}){ }^{59}$ is $\mathrm{K}_{0.02} \mathrm{Na}_{0.08} \mathrm{Ca}_{0.50} \mathrm{Mg}_{0.30} \mathrm{Fe}_{0.11} \mathrm{Al}_{0.54} \mathrm{SiO}_{3.77}$. The density of the fibers was determined from the chemical composition and used for determining the specific surface area (eq 1).

The proportion of organic material, determined from the loss of sample mass during heating to $600{ }^{\circ} \mathrm{C}$ using the TG, was compared with LOI measurements of unsieved stone wool after heating at $590{ }^{\circ} \mathrm{C}$ (Table 2). Mass loss could be attributed to organic material decomposition, over the range from $110^{\circ} \mathrm{C}$ to the final temperature. The mass loss below 110 ${ }^{\circ} \mathrm{C}$ was interpreted as water evaporation. The results of LOI were closer than TG results to the actual amount of binder that had been deposited on the samples during production, probably because of higher sample mass used in the LOI experiments and thus better sample representability. However,

Table 2. Bulk Composition (Major Components), Density, Organic Material Content, Mean Diameter, and Surface Area for All Fiber Samples

\begin{tabular}{|c|c|c|c|c|c|c|c|c|c|c|c|c|}
\hline \multirow[b]{2}{*}{ sample } & \multicolumn{7}{|c|}{ XRF results, wt \% } & \multirow[b]{2}{*}{ density, $\mathrm{g} / \mathrm{cm}^{3}$} & \multicolumn{2}{|c|}{$\begin{array}{c}\text { organic content, } \\
\text { wt } \%\end{array}$} & \multirow[b]{2}{*}{$d_{50}, \mu \mathrm{m}$} & \multirow[b]{2}{*}{ surface area, $\mathrm{cm}^{2} / \mathrm{g}$} \\
\hline & $\mathrm{SiO}_{2}$ & $\mathrm{Al}_{2} \mathrm{O}_{3}$ & $\mathrm{FeO}$ & $\mathrm{CaO}$ & $\mathrm{MgO}$ & $\mathrm{Na}_{2} \mathrm{O}$ & $\mathrm{K}_{2} \mathrm{O}$ & & TG & LOI & & \\
\hline $\mathrm{F} 1$ & 42.0 & 19.1 & 5.5 & 19.5 & 8.5 & 1.8 & 0.7 & 2.8 & 0.3 & 0.2 & 3.4 & 2629 \\
\hline $\mathrm{F} 2$ & 42.0 & 19.0 & 5.6 & 19.3 & 8.6 & 1.8 & 0.8 & 2.8 & 2.7 & 2.1 & 3.7 & 2451 \\
\hline F3 & 42.0 & 18.8 & 5.6 & 19.3 & 8.6 & 1.8 & 0.8 & 2.8 & 2.7 & 3.6 & 3.7 & 2437 \\
\hline F4 & 42.0 & 18.8 & 5.8 & 19.2 & 8.6 & 1.8 & 0.9 & 2.8 & 7.9 & 6.3 & 3.9 & 2371 \\
\hline uncertainty & \pm 0.4 & \pm 0.3 & \pm 0.2 & \pm 0.2 & \pm 0.2 & \pm 0.1 & \pm 0.1 & - & - & - & \pm 0.5 & - \\
\hline
\end{tabular}


TG results confirmed that there was no loss of organic material on the fibers due to sieving procedure and that the sieved fiber materials used in dissolution and surface characterization studies had the desired amount of binder.

Surface composition, determined with XPS, is shown in Table 3. With increasing organic material, the atom\% of $\mathrm{C}$

Table 3. XPS Surface Composition (at.\%) of All Fiber Samples Prior to the Dissolution Experiments ${ }^{a}$

\begin{tabular}{|c|c|c|c|c|}
\hline sample & F1 & $\mathrm{F} 2$ & F3 & F4 \\
\hline $\mathrm{O}$ & $34.5 \pm 0.2$ & $10.1 \pm 0.7$ & $9.1 \pm 0.7$ & $8.1 \pm 0.1$ \\
\hline $\mathrm{C}$ & $31.3 \pm 0.3$ & $78.9 \pm 1.7$ & $80.9 \pm 0.8$ & $83.0 \pm 0.2$ \\
\hline $\mathrm{N}$ & $2.4 \pm 0.1$ & $2.5 \pm 0.1$ & $2.5 \pm 0.1$ & $2.4 \pm 0.1$ \\
\hline $\mathrm{Ca}$ & $5.3 \pm 0.1$ & $1.4 \pm 0.1$ & $1.2 \pm 0.2$ & $0.9 \pm 0.1$ \\
\hline $\mathrm{Mg}$ & $3.6 \pm 0.1$ & $1.0 \pm 0.4$ & $0.9 \pm 0.3$ & $0.6 \pm 0.1$ \\
\hline $\mathrm{Si}$ & $12.7 \pm 0.2$ & $3.4 \pm 0.4$ & $2.9 \pm 0.1$ & $2.6 \pm 0.2$ \\
\hline $\mathrm{Al}$ & $6.6 \pm 0.3$ & $1.8 \pm 0.3$ & $1.4 \pm 0.2$ & $1.3 \pm 0.1$ \\
\hline$S$ & 0 & $0.8 \pm 0.1$ & $0.9 \pm 0.2$ & $0.7 \pm 0.1$ \\
\hline $\mathrm{Fe}$ & $0.7 \pm 0.1$ & $0.1 \pm 0.1$ & $0.1 \pm 0.1$ & $0.2 \pm 0.1$ \\
\hline $\mathrm{Na}$ & $0.9 \pm 0.1$ & $0.1 \pm 0.1$ & $0.1 \pm 0.1$ & 0 \\
\hline K & $0.5 \pm 0.1$ & 0 & 0 & 0 \\
\hline $\mathrm{Cl}$ & $0.8 \pm 0.1$ & 0 & 0 & 0 \\
\hline \multicolumn{5}{|l|}{ Ratio } \\
\hline $\mathrm{C} / \mathrm{Si}$ & 2.5 & 23.2 & 27.8 & 31.4 \\
\hline $\mathrm{N} / \mathrm{C}$ & 0.078 & 0.032 & 0.031 & 0.029 \\
\hline
\end{tabular}

${ }^{a}$ Heavy metal concentrations were below detection.

determined with XPS increased, while the content of other elements on the surface decreased, but this is completely logical because the data are relative surface concentration and more organic material masks the material that is deeper in the sample. XPS is extremely surface sensitive, probing a depth of no more than $10 \mathrm{~nm}$. More binder leads to an increase for the elements typical for PUF, oil, and APS ( $\mathrm{C}$ and $\mathrm{N}$ ) and a decrease of the elements typical for the inorganic fibers $(\mathrm{Si}, \mathrm{Al}$, $\mathrm{Fe}, \mathrm{Ca}, \mathrm{Mg}, \mathrm{Na}, \mathrm{K}$ ). The $\mathrm{C} / \mathrm{Si}$ XPS ratio increases with the range of organic material, determined with TG and LOI. The N/C XPS ratio for the samples with PUF binder (F2-F4) is constant, indicating that PUF deposited on the fiber surface has a similar composition for all samples. For samples F2-F4, a small amount of sulfur was detected which originates from ammonium sulfate that is added to the PUF binder during production to decrease $\mathrm{pH}$ during binder curing.

3.2. Static Batch Dissolution Tests Results. Figure 3 presents the solution composition (AAS) data from each day of the $4 \mathrm{~d}$ of batch experiments, made at $\mathrm{pH} 4.5$ and temperature of $37^{\circ} \mathrm{C}$ in the synthetic lung fluid. The $\mathrm{pH}$ was adjusted to 4.5 once a day, because of its increase to 4.9 caused by fiber dissolution. After $4 \mathrm{~d}$ of dissolution the ratio $\mathrm{Ca}: \mathrm{Mg}: \mathrm{Fe}: \mathrm{Al}: \mathrm{Si}$ is equal to $0.63: 0.41: 0.13: 0.55: 1$, which is close to the stoichiometric formula of stone wool fibers, $\mathrm{K}_{0.02} \mathrm{Na}_{0.08} \mathrm{Ca}_{0.50} \mathrm{Mg}_{0.30} \mathrm{Fe}_{0.11} \mathrm{Al}_{0.54} \mathrm{SiO}_{3.77} . \mathrm{Ca}$ and $\mathrm{Mg}$ are preferentially leaching. The ratio for the matrix formers, $\mathrm{Al}$ and $\mathrm{Si}$, resembles that in the bulk, so we conclude that fiber dissolution in synthetic lung fluid is close to congruent. An important conclusion is that we were unable to demonstrate any significant difference in dissolution rate or extent whether the fibers were without binder (F1) or with it (F2-F4). The presence of PUF binder, which is the major component of organic material, had no influence on dissolution of the fiber in the synthetic lung fluid. After $4 \mathrm{~d}$ of dissolution, $\mathrm{Si}$ concentration was $\sim 0.8 \mathrm{mmol} / \mathrm{L}$ for all samples. Dissolution rate determined from $\mathrm{Si}$ concentration in the effluent over time (Figure 3) was $154 \mathrm{ng} / \mathrm{cm}^{2} / \mathrm{h}$ based on $\mathrm{Si}$ or $770 \mathrm{ng} / \mathrm{cm}^{2} / \mathrm{h}$ based on fiber dissolution, assuming congruent dissolution. After $4 \mathrm{~d}, 81 \%$ of the initial sample remained.

For all elements, the change in concentration with time is described using equation: ${ }^{60,61}$

$$
c=c_{\mathrm{s}}\left(1-\exp \left(-k \frac{S}{V} t\right)\right)
$$

where $c$ represents concentration in $\mathrm{mmol} / \mathrm{L}, \quad c_{\mathrm{s}}$ is the concentration at saturation or equilibrium concentration in $\mathrm{mmol} / \mathrm{L}, k$ is the rate constant in $\mathrm{m} / \mathrm{s}, S$ is solid surface area in $\mathrm{m}^{2}, V$ is the solution volume in $\mathrm{m}^{3}$, and $t$ stands for time in $\mathrm{s}$. In case of amorphous $\mathrm{SiO}_{2}{ }^{62}$ or glass with low $\mathrm{Al}$ content, ${ }^{63}$ the dissolution rate decreases for all elements as the solution approaches saturation. This can be described by the formation of silicic acid in the solution by the reaction: ${ }^{62}$

$$
\mathrm{SiO}_{2}(\mathrm{~s})+\mathrm{H}_{2} \mathrm{O}=\mathrm{H}_{4} \mathrm{SiO}_{4}(\mathrm{aq}) \quad K=10^{-2.71}
$$
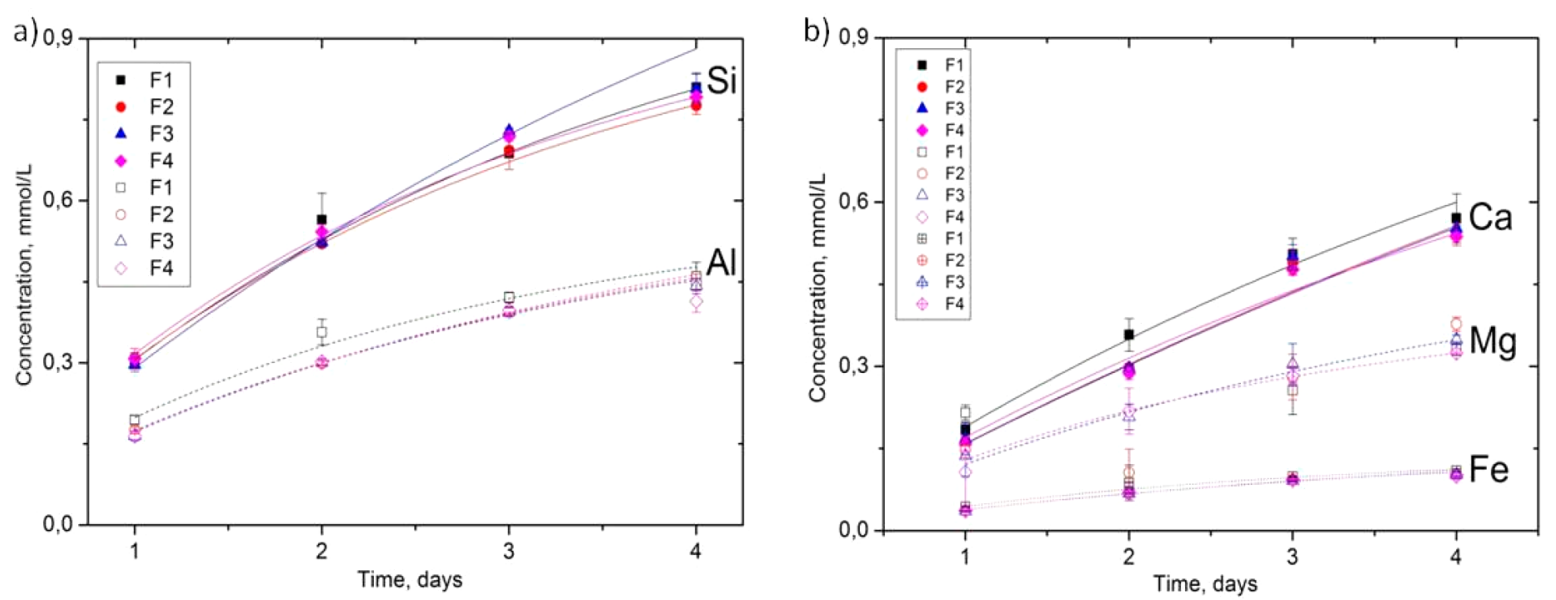

Figure 3. Concentration of (a) Si (full symbols) and $\mathrm{Al}$ (empty symbols) and (b) Ca (full symbols), $\mathrm{Mg}$ (empty symbols), and Fe (crossed symbols) determined with AAS for stone wool fiber samples with different amounts of binder (F1-F4) during $4 \mathrm{~d}$ batch dissolution experiments in synthetic lung fluid at $37^{\circ} \mathrm{C}$. 


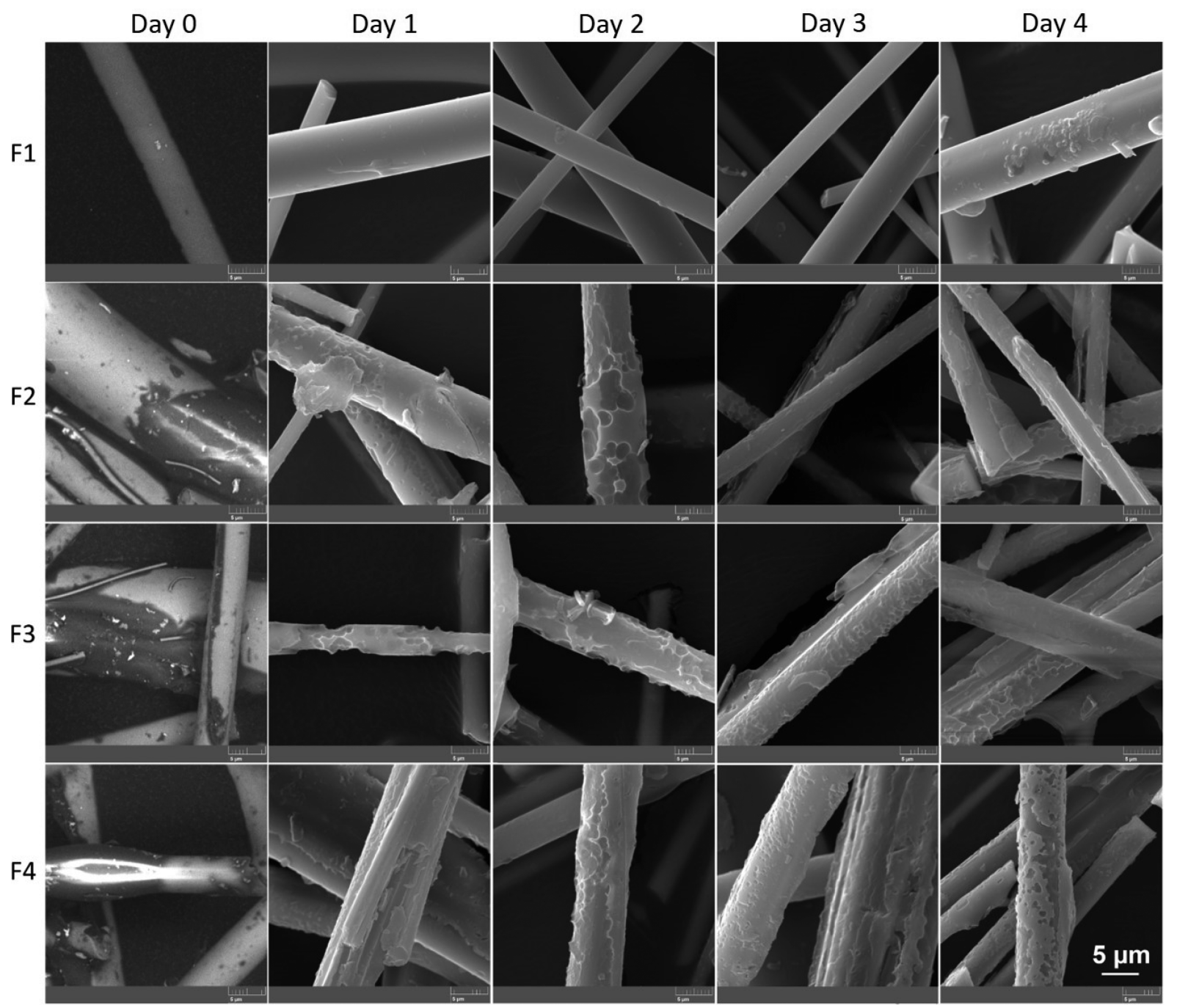

Figure 4. SEM images of the stone wool fibers samples F1-F4 (in rows) before (day 0, imaged with BSE $5 \mathrm{kV}$ ) and after static batch dissolution experiments from days 1 to 4 (imaged with SE $30 \mathrm{kV}$ ) (columns) in the synthetic lung fluid at $37^{\circ} \mathrm{C}$.

At the investigated $\mathrm{pH} 4.5$, silicic acid is in its protonated form, and thus saturation concentration of $\mathrm{Si}$ in the solution, $c_{\mathrm{s}}$, is $10^{-2.71} \mathrm{~mol} / \mathrm{L}(1.9 \mathrm{mmol} / \mathrm{L})$. According to eq 2 , when the concentration of silicic acid reaches saturation, the dissolution rate becomes zero. In our fitting for all stone wool fiber samples, $c_{\mathrm{s}}$ for $\mathrm{Si}$ was significantly lower than the saturation level of silicic acid, at $\sim 1.1 \mathrm{mmol} / \mathrm{L}$. This means that for stone wool fiber dissolution in synthetic lung fluid, dissolution is probably not only controlled by release of silicic acid from the glass matrix. For $\mathrm{Al}, c_{\mathrm{s}}$ is $0.56 \mathrm{mmol} / \mathrm{L}$ and for and $\mathrm{Fe}, 0.14$ $\mathrm{mmol} / \mathrm{L}\left(0.7 \mathrm{mmol} / \mathrm{L}\right.$ of total $\mathrm{Me}^{3+}$, assuming that released $\mathrm{Fe}^{2+}$ from fibers is instantly oxidized and converted to $\mathrm{Fe}^{3+}$ in the solution). It is known that at $\mathrm{pH} 4.5$, citrate in excess forms complexes with the stoichiometry metal-ligand, Me: $\mathrm{L}=1: 2$ for $\mathrm{Al}^{64,65}$ and $1: 1$ for $\mathrm{Fe}(\mathrm{III}){ }^{66,67}$ Tartrate forms complexes with stoichiometry, Me:L = 1:1 with both $\mathrm{Al}^{68}$ and $\mathrm{Fe}^{69,70}$ In our system, concentrations of citrate and tartrate are 0.52 and $0.78 \mathrm{mmol} / \mathrm{L}$, which results in binding of $1.13 \mathrm{mmol} / \mathrm{L}$ of $\mathrm{Me}^{3+}$. Thus, we expect that stone wool fiber dissolution slows after $4 \mathrm{~d}$ because of decreased free citrate and tartrate.

Morphology changes of the stone wool fibers after the static batch dissolution experiments were observed with SEM (Figure 4). Fibers without binder (F1) showed no significant morphology changes. However, for stone wool fibers with binder (F2-F4), we saw similar morphological changes, caused by the dissolution. Cavities of irregular shape and size formed on the fibers already after $24 \mathrm{~h}$. Presumably, the treated fibers dissolved more readily where binder droplets were absent, resulting in inhomogeneous dissolution for samples F2-F4. Uncoated fibers dissolved evenly, with no cavity formation. Similar morphology changes were also reported in dissolution experiments with Gamble's solution at $\mathrm{pH} 7.4$ and 4.5 , but for stone and glass wool samples where organic resin and oil were not present. ${ }^{9}$

The surface analysis shows changes in the ratios for $\mathrm{Al} / \mathrm{Si}$, $\mathrm{Ca} / \mathrm{Si}, \mathrm{Mg} / \mathrm{Si}$, and $\mathrm{C} / \mathrm{Si}$ (Figure 5). After dissolution, surfaces are enriched with $\mathrm{Si}$ and depleted with other elements, including $\mathrm{Al}$. In synthetic lung fluid containing $\mathrm{Al}$ complexing agents, that is, citrate and tartrate, $\mathrm{Al}$ dissolution is favored so surface accumulation was not observed.

The surface $\mathrm{C}$ to $\mathrm{Si}$ ratio decreases for all samples during dissolution in the synthetic lung fluid, mainly because of increasing Si concentration, rather than decreased surface $\mathrm{C}$ (Supporting Information, Table S1). This is consistent with SEM observations, where parts of the fibers that had been 


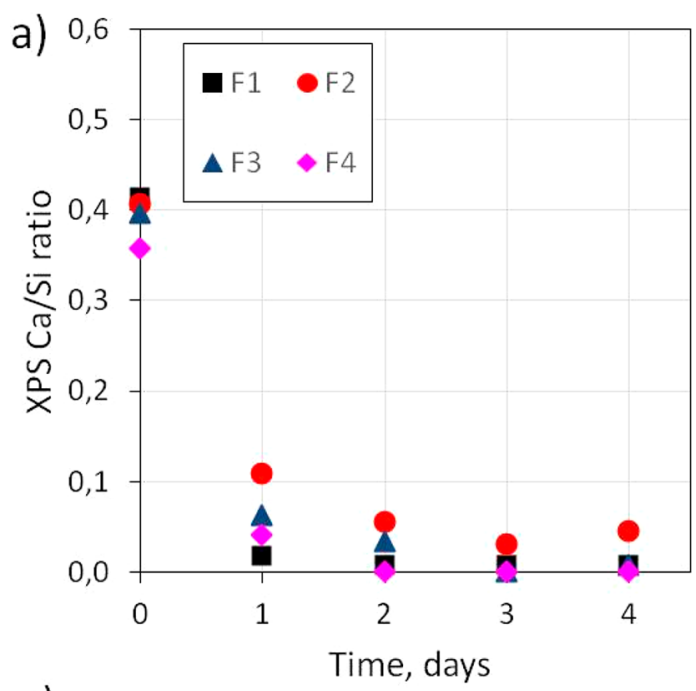

b)
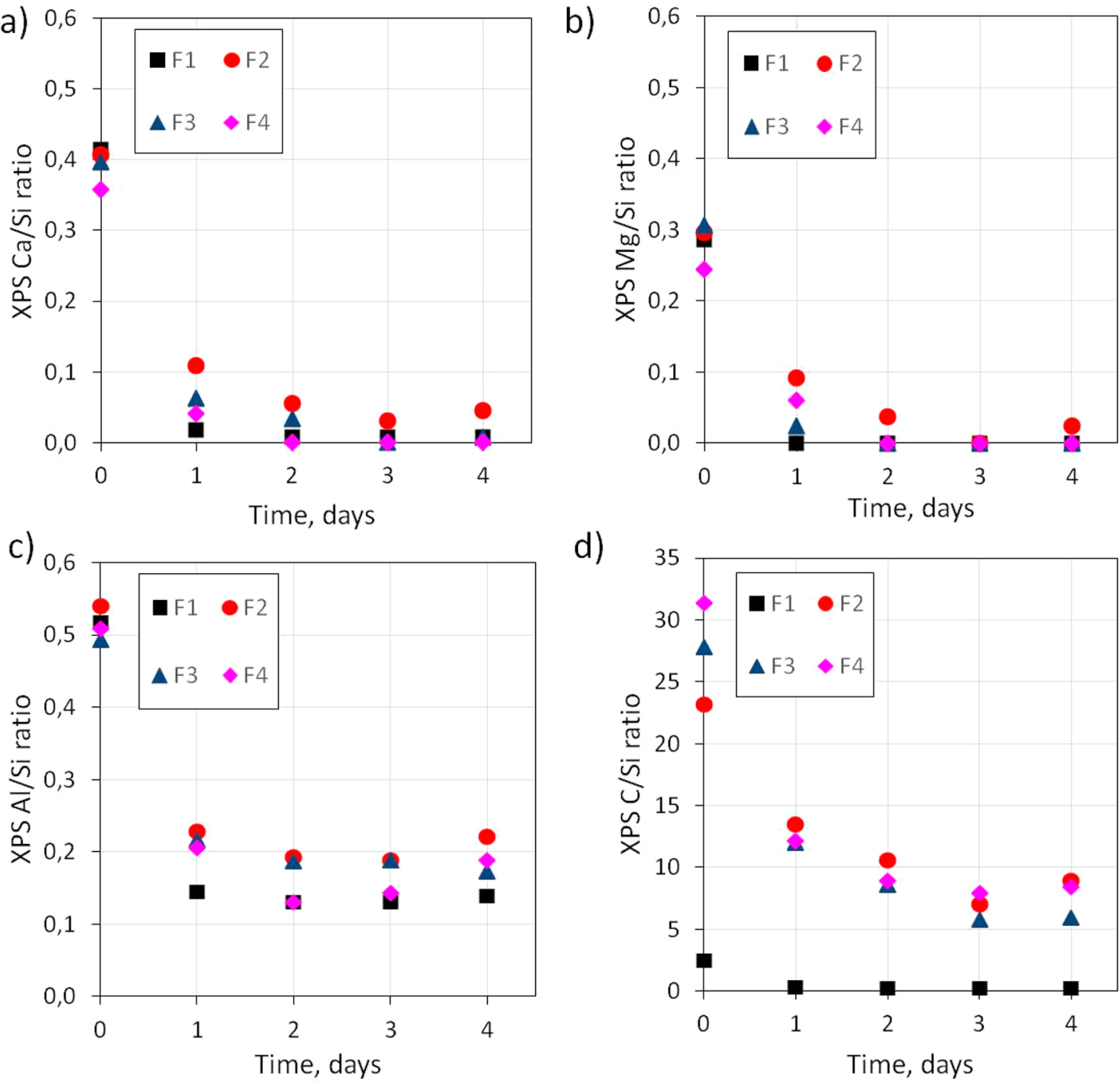

d)

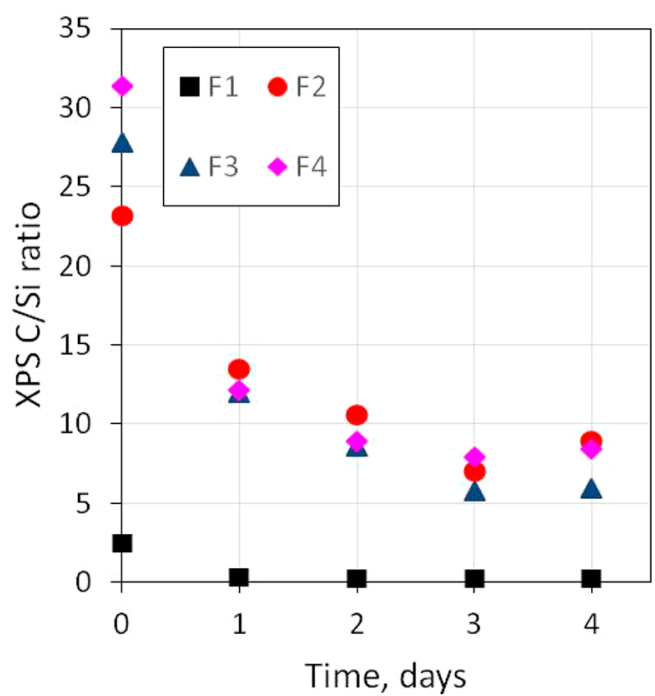

Figure 5. Surface concentration (XPS) ratios (a) $\mathrm{Ca} / \mathrm{Si}$, (b) $\mathrm{Mg} / \mathrm{Si}$, (c) $\mathrm{Al} / \mathrm{Si}$, and (d) $\mathrm{C} / \mathrm{Si}$ during dissolution in synthetic lung fluid at $37^{\circ} \mathrm{C}$ over $4 \mathrm{~d}$ for stone wool fiber samples with different amounts of binder (F1-F4).
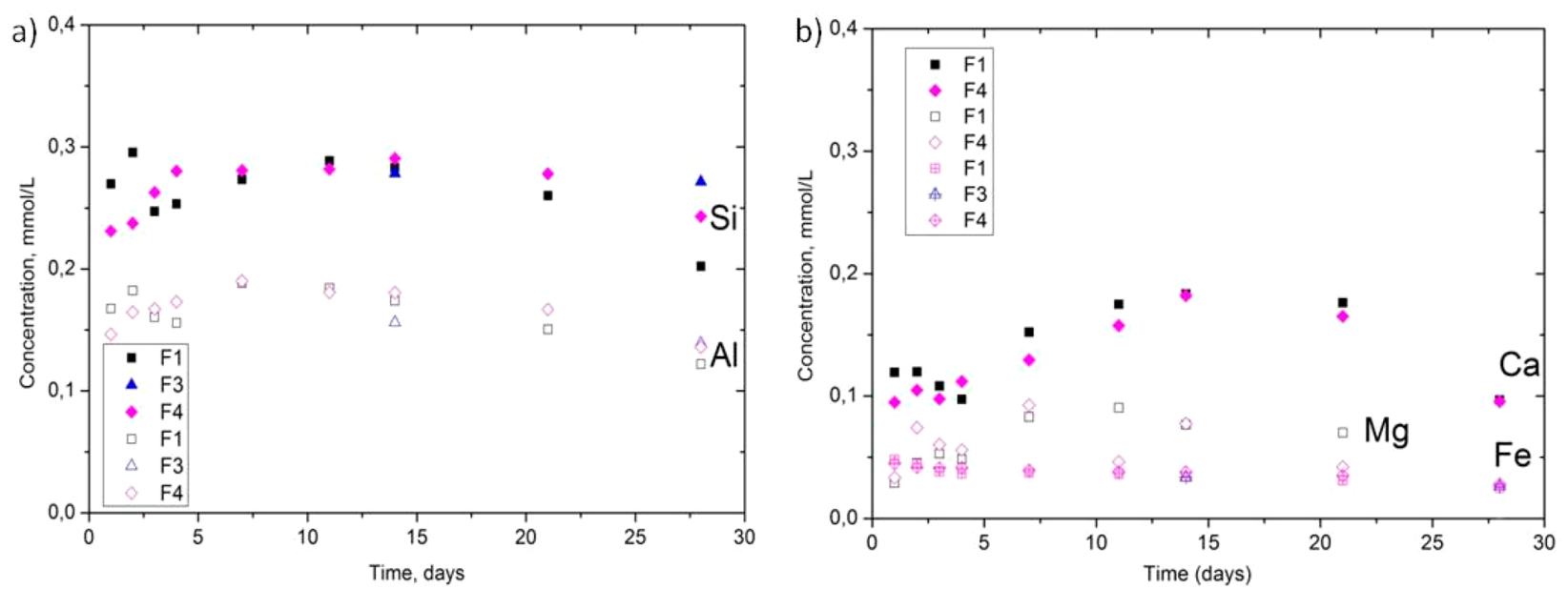

Figure 6. Concentrations of (a) Si (full symbols) and $\mathrm{Al}$ (empty symbols) and (b) Ca (full symbols), $\mathrm{Mg}$ (empty symbols), and Fe (crossed symbols) determined with AAS for stone wool samples with different amounts of binder (F1, F3, and F4) dissolving in synthetic lung fluid over 28 d constant flow experiments at $37^{\circ} \mathrm{C}$.

treated with binder are not dissolved and other parts, where binder droplets are absent, dissolve forming cavities (Figure 4).
3.3. Dynamic Flow Experiments. From the results of the static dissolution experiments, we concluded that $\mathrm{Al}$ and $\mathrm{Fe}$ 

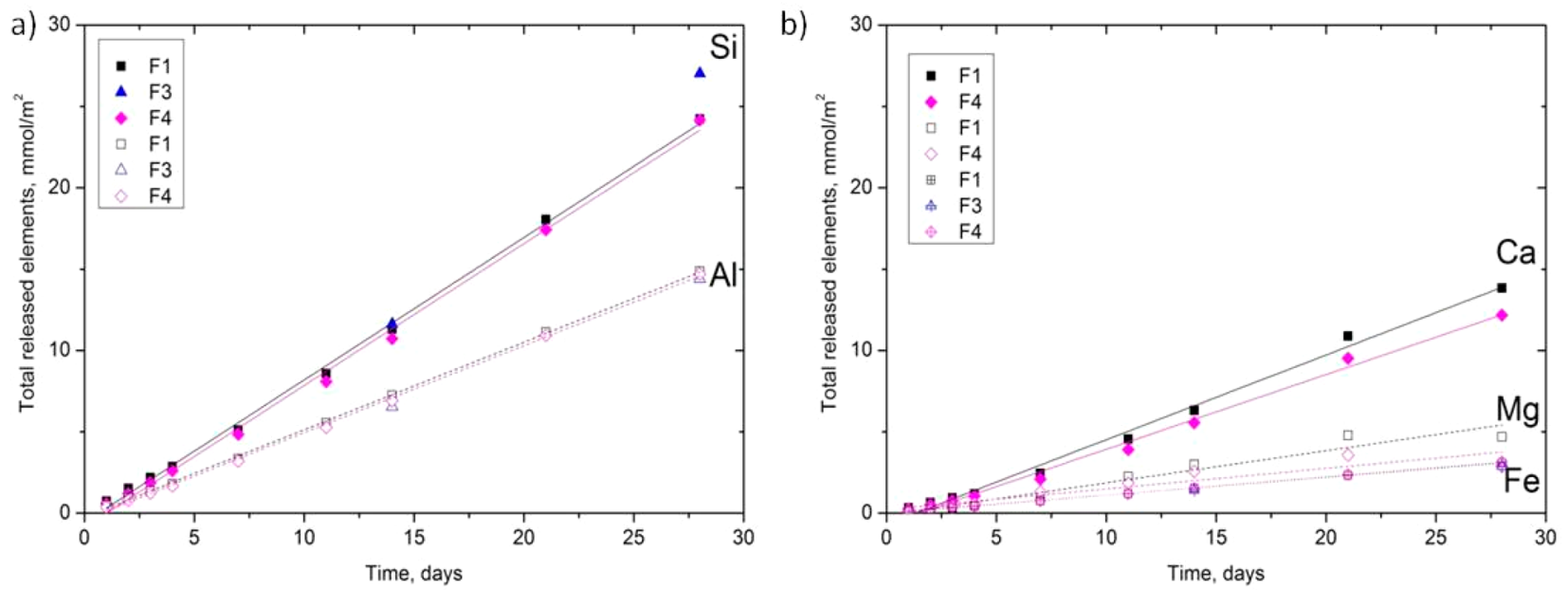

Figure 7. Total accumulated concentration of dissolved elements normalized by surface area (a) Si (full symbols) and Al (empty symbols) and (b) $\mathrm{Ca}$ (full symbols), Mg (empty symbols), and Fe (crossed symbols) determined with AAS and for stone wool samples with different amounts of binder (F1, F3, and F4) over the $28 \mathrm{~d}$ flow through experiments at $37{ }^{\circ} \mathrm{C}$ in synthetic lung fluid.

Table 4. Fitting Results for Element Release Rate, the Rate Ratio, and $\log \mathbf{r}_{+}$for Silica

\begin{tabular}{|c|c|c|c|c|c|c|c|}
\hline \multirow[b]{2}{*}{ sample } & \multicolumn{5}{|c|}{ release rate, $10^{-9} \mathrm{~mol} / \mathrm{m}^{2} / \mathrm{s}$} & \multirow[b]{2}{*}{ release rate ratio, $\mathrm{Ca}: \mathrm{Mg}: \mathrm{Fe}: \mathrm{Al}: \mathrm{Si}$} & \multirow[b]{2}{*}{$\log \mathrm{r}_{+}, \mathrm{mol}(\mathrm{Si}) / \mathrm{cm}^{2} / \mathrm{s}$} \\
\hline & $\mathrm{Ca}$ & $\mathrm{Mg}$ & $\mathrm{Fe}$ & $\mathrm{Al}$ & $\mathrm{Si}$ & & \\
\hline $\mathrm{F} 1$ & 6.03 & 2.29 & 1.27 & 6.23 & 10.1 & 0.59:0.23:0.13:0.61:1 & -12.0 \\
\hline $\mathrm{F} 4$ & 5.31 & 1.46 & 1.30 & 6.19 & 10.1 & $0.53: 0.14: 0.13: 0.61: 1$ & -12.0 \\
\hline
\end{tabular}

complexing agents have a significant role in the stone wool dissolution process. As the system approached equilibrium, the citrate and tartrate are complexed, leading to a drop in dissolution rate (Figure 3). To avoid this, we made constant flow experiments, where the composition of the solution passing through the stone wool fiber samples was held constant. Figure 6 presents the concentrations for $\mathrm{Si}, \mathrm{Al}, \mathrm{Fe}$, $\mathrm{Ca}$, and $\mathrm{Mg}$ for samples F1, F3, and F4 over $28 \mathrm{~d}$.

During the first week, except for Fe, the concentrations of all elements increase, then decrease after 11-14 d, causing effluent $\mathrm{pH}$ increase to 5.3 followed by decrease to 5.0 after 2 weeks. The decline in the element concentration after $14 \mathrm{~d}$ could be explained by a significant decrease in surface area as the mass of the fibers decreases to $<50 \%$ of the original. To estimate the decrease of surface area over the course of the experiments, we estimated the loss of the stone wool mass (Supporting Information Figure S1) from the amount of released silica, shown in Figure 6a, assuming congruent dissolution, which is a reasonable assumption, considering the ratios for the released elements presented in Figure 6a,b. The mass loss of the fibers leads to decrease in the fiber radius. Assuming that fibers are elongated cylinders, the average fiber radius before dissolution can be found using

$$
r_{0}=\frac{2}{S \times \rho}
$$

where $r_{0}$ stands for the average fiber radius before dissolution, $S$ is the specific surface area (Table 2), and $\rho$ is the density of the fibers (Table 2). During dissolution, the decrease of fiber radius is related to mass loss:

$$
r_{1}=\sqrt{\frac{m_{1}}{m_{0}}} r_{0}
$$

where $r_{1}$ represents average fiber radius after dissolution, $m_{0}$ is initial fiber mass, and $m_{1}$ is fiber mass after dissolution. By introducing $r_{1}$ from eq 5 into eq 4 and rearranging it, it is possible to estimate change in fiber surface area during dissolution. The quantity of the released elements was normalized using this surface area. The total release of all elements is shown in Figure 7.

We determined the dissolution rates for all elements using slopes of the linear fit to the element concentrations over time (Figure 7). The results of fitting are shown in Table 4 in different units: $\mathrm{mol} / \mathrm{m}^{2} / \mathrm{s}$ for all measured elements and $\log \mathrm{r}_{+}$ $\left(\mathrm{mol} / \mathrm{cm}^{2} / \mathrm{s}\right)$ for $\mathrm{Si}$, where $\mathrm{r}_{+}$stands for the rate of the dissolution reaction. The $\log r_{+}\left(\mathrm{mol}(\mathrm{Si}) / \mathrm{cm}^{2} / \mathrm{s}\right)$ is widely used for the natural basalts dissolution, ${ }^{71,72}$ and we used it for comparison with these published data. The goodness of linear fit, $R^{2}$, for the experimental data in Figure 7 was better than 0.98 for all elements, except $\mathrm{Mg}$. The deviation from linearity for $\mathrm{Mg}$ is caused by its concentrations determined in outlet solution after $14 \mathrm{~d}$ of the dissolution. After $14 \mathrm{~d}$, concentrations of all elements in the outlet solution started to decline (Figure 6), because of the decrease of fiber surface area available for dissolution. In the synthetic lung fluid used for fiber dissolution, concentration of $\mathrm{Mg}$ is quite high (Table 1 ), and thus the concentration of $\mathrm{Mg}$ released from fibers after $14 \mathrm{~d}$ was just above the background. This makes it difficult for estimating the correct $\mathrm{Mg}$ amount released from fibers after 14 d. The element release rates reflect the trend for the stoichiometric ratio of the elements in the bulk stone wool fibers. For samples F1 (without binder) and F4 (with maximum applied binder), element release rates are similar throughout the $28 \mathrm{~d}$ of dissolution. For sample F3, we did not determine dissolution rate, because only the data for days 14 and 28 were available. However, $\mathrm{Si}, \mathrm{Al}$, and $\mathrm{Fe}$ concentrations for F3 are consistent with the concentrations from F1 and F4, so we expect no significant difference in dissolution rate for F3. 
Thus, we can conclude that the presence of binder on stone wool fibers has negligible influence on the rate of fiber dissolution in the synthetic lung fluid. Si release rate is $102 \mathrm{ng} /$ $\mathrm{cm}^{2} / \mathrm{h}$ for $\mathrm{F} 1$ and $\mathrm{F} 4$, and assuming congruent dissolution, we estimate stone wool fiber dissolution rate of $508 \mathrm{ng} / \mathrm{cm}^{2} / \mathrm{h}$ for $\mathrm{F} 1$ and F4. The rate of Si release for our samples is higher than for fiber dissolution at $\mathrm{pH} 4.5$ in solutions without Alcomplexing agents. ${ }^{44}$ Gislason and Oelkers ${ }^{71}$ reported dissolution rates, $\log \mathrm{r}_{+}(\mathrm{Si})\left(\mathrm{mol}(\mathrm{Si}) / \mathrm{cm}^{2} / \mathrm{s}\right)$, of -14.17 (at $25{ }^{\circ} \mathrm{C}$ ) and $-13.67\left(\right.$ at $50{ }^{\circ} \mathrm{C}$ ) at $\mathrm{pH} 4.5$ in the absence of $\mathrm{Al}$ complexing agents, for basaltic glass with bulk composition not far from our samples, $\mathrm{Na}_{0.08} \mathrm{Ca}_{0.263} \mathrm{Mg}_{0.281} \mathrm{Fe}_{0.188} \mathrm{Al}_{0.358} \mathrm{SiO}_{3.32}$. However, dissolution rate increased by $1-2$ orders of magnitude at $\mathrm{pH}$ between 3 and 7 in the presence of oxalate. ${ }^{72}$

Surface analysis of the stone wool fibers at the end of the 28 d flow experiment showed results similar to those from batch dissolution. The $\mathrm{Al} / \mathrm{Si}$ ratio decreased from 0.5 to 0.1 for all samples and $\mathrm{Ca} / \mathrm{Si}, \mathrm{Mg} / \mathrm{Si}$ and $\mathrm{Fe} / \mathrm{Si}$ dropped to zero, indicating surface $\mathrm{Si}$ enrichment (Supporting Information Table S2). For samples F3 and F4, decrease of the carbon ratio to silica was similar to batch experiments, and morphology changes were also similar to what we saw after $4 \mathrm{~d}$ from the batch experiments (Figure 4). No morphology changes were observed for sample F1 (Figure 8a), but fibers with binder,

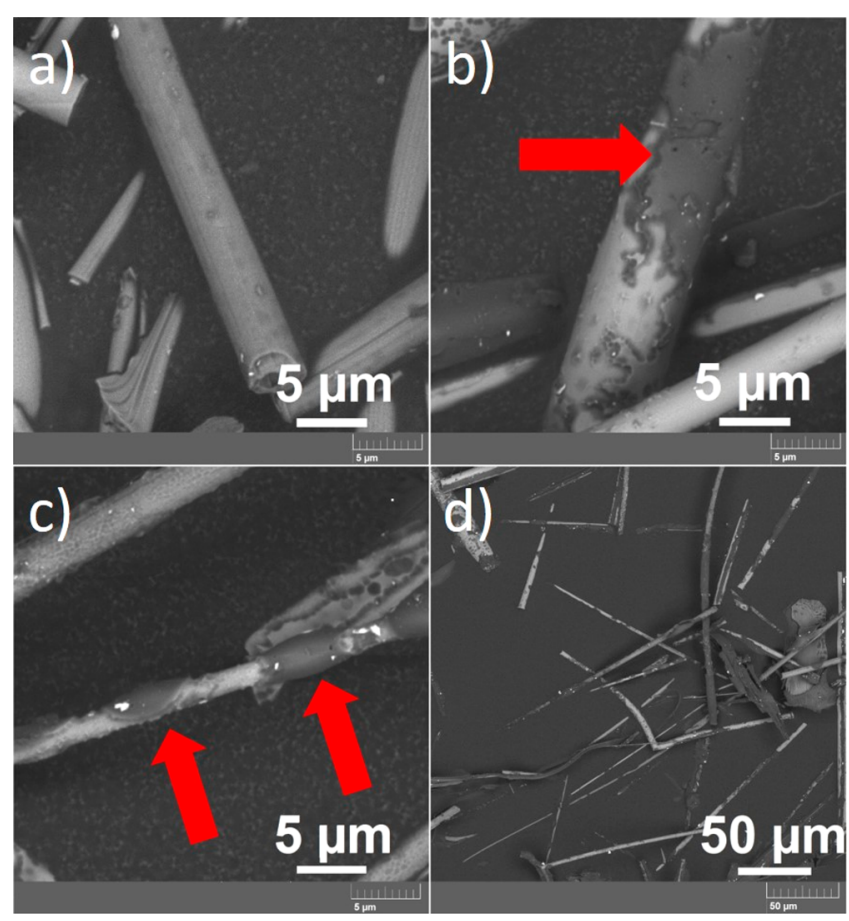

Figure 8. SEM images (BSE $5 \mathrm{kV}$ ) of the stone wool fibers samples: (a) F1, (b) F3, and (c, d) F4 after dissolution for $28 \mathrm{~d}$ in the synthetic lung fluid at $37^{\circ} \mathrm{C}$. Red arrows indicate areas where binder is present after dissolution of F3 and F4 samples.

samples F3 and F4, showed more pronounced changes after 28 $\mathrm{d}$ than after $4 \mathrm{~d}$ in the batch reactors (Figure $8 \mathrm{~b}-\mathrm{d}$ ). To determine the composition of binder droplets, seen in the Figure $8 \mathrm{~b}-\mathrm{d}$ for F3 and F4 samples, we performed EDXS analysis on single fiber.

EDXS line scan analysis was done where the binder droplets are presumably located (Figure 9a,b). Figure 9a shows a fiber with binder that had been dissolving for $28 \mathrm{~d}$ in synthetic lung fluid at $37^{\circ} \mathrm{C}$. Cavities formed between the patches where we see binder droplets. EDXS shows that the material in the cavities was composed of elements typical for stone wool fiber composition, for example, $\mathrm{Si}, \mathrm{Al}$, and $\mathrm{Mg}$, and no $\mathrm{C}$, which is typical for the binder. The areas of binder gave a high signal for C. The thickness of this material resulted in almost no signal for inorganic constituents of the underlying fibers. Thus, we can confirm that the fibers dissolve around the areas with organic material droplets. However, it is also clear from Figure 9a that dissolution extends beneath the binder droplets and can potentially lead to detachment of the organic material. The left binder droplet could be detached from the fiber surface. Detachment of binder droplets can explain decreased carbon content on surfaces, and cavity formation on the uncoated areas explains increase of $\mathrm{Si}$ observed as decreased $\mathrm{C} / \mathrm{Si}$ ratio in the XPS analyses (Supporting Information Table S2), from 31 to 20 for sample F4 and from 28 to 14 for sample F3.

\section{DISCUSSION}

From the SEM images (Figures 1 and 8-10), we can see that the binder does not smoothly coat the fiber surfaces for any of the samples investigated, but instead is distributed as droplets on the fiber surface. Organic material on the stone wool fiber surfaces could potentially affect the dissolution rate of the fibers in the aqueous media, ${ }^{50-53}$ especially if it forms a homogeneous, impermeable coating. Therefore, binder distribution on the stone wool fibers is a critical factor for dissolution. At the current stage, the fraction of the fiber coated with organics is not quantified. QUASES-XPS modeling proposed that fibers treated with binder may contain $4 \mathrm{~nm}$ organic surface layer, which presumably consists of binder material and oil, and can be partially destroyed and rearanged upon contact with water at elevated temperatures. ${ }^{73}$ In the production of stone wool fibers, organic matter is sprayed on the fibers in water emulsion which results in inhomogeneous distribution of binder over the fibers surface. Increasing the amount of binder from 2 to $6 \%$ during production does not lead to a significant change in the homogeneity of the binder distribution or to the formation of impermable layer on the fiber, as seen in the SEM images (Figures 10). Coverage is still very low, leaving considerable surface area free for attack by the solution.

For the untreated fibers, high dissolution rate leads to homogeneous dissolution with overall decrease of fiber diameter, whereas for samples with binder, cavities form in the areas where binder droplets are not present (Figures $8-9$ ) but the mass of material moving from the solid to the solution is the same. Thus, proposed by modeling with QUASES-XPS, a $4 \mathrm{~nm}$-thick surface organic layer ${ }^{73}$ is not sufficient to protect the fibers. The solution has access to the fiber that was treated with binder so the dissolution rate is unaffected and cavities formation increases the surface area available for the dissolution. Morphology change and formation of cavities are observed already after day 1, and Figure 9 shows that binder droplets can be potentially displaced from fiber surfaces when the cavities extend beneath them. Cavity formation and inhomogeneous dissolution are also observed in in vivo biopersistence studies with biosoluble stone wool fibers with no binder added. Cavities locally reduce the thickness and the mechanical strength of the fibers, leading to breakage of the fibers into shorter fragments that can be mechanically cleared by the macrophages. ${ }^{17} \mathrm{We}$ suggest that dissolution of the samples with binder proceeds as shown in Figure 11. 


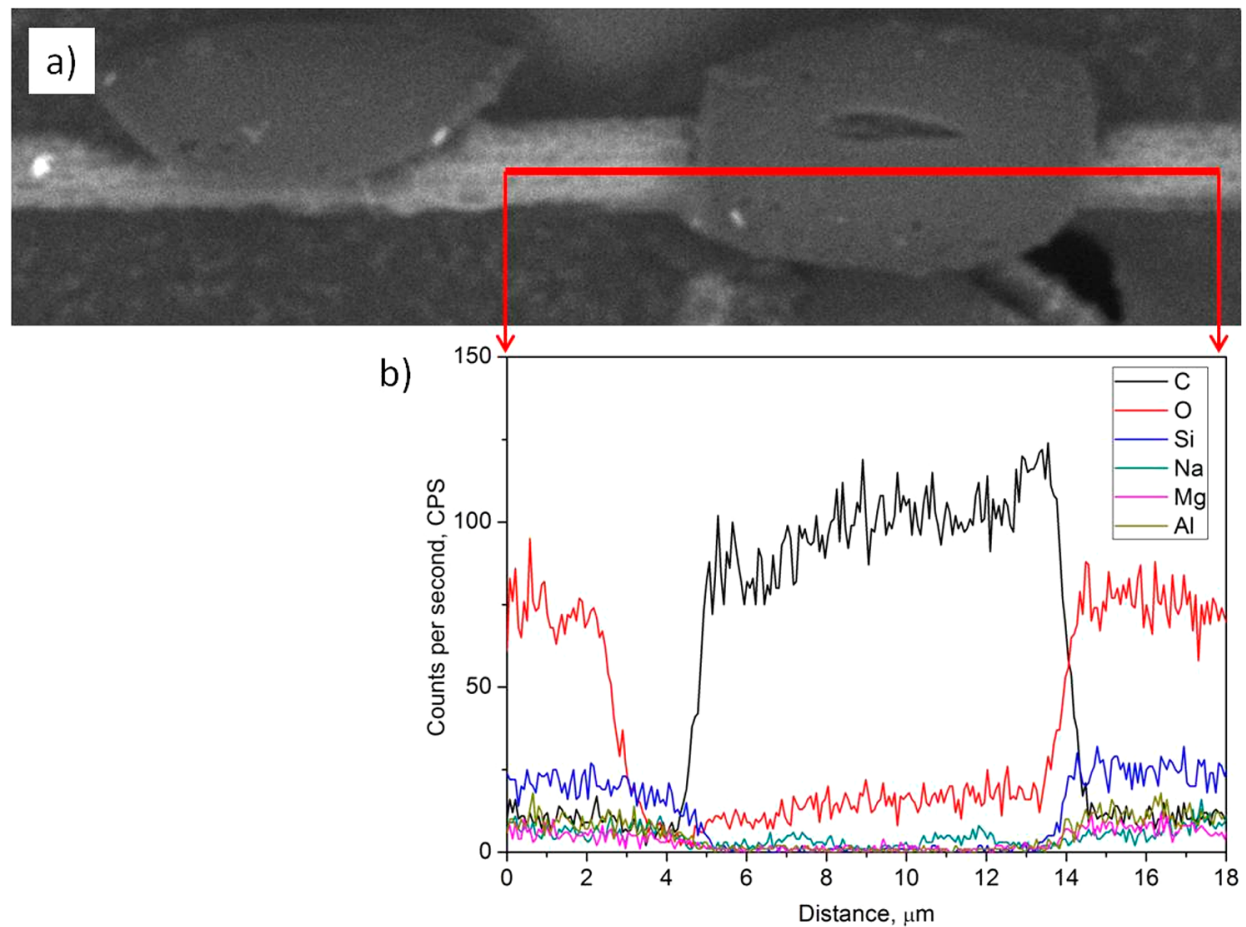

Figure 9. (a) SEM image and (b) EDXS line scan (red line) on a single fiber from F4 after dissolution for $28 \mathrm{~d}$ in the synthetic lung fluid at $37^{\circ} \mathrm{C}$. The left binder droplet is detached from the fiber surface.

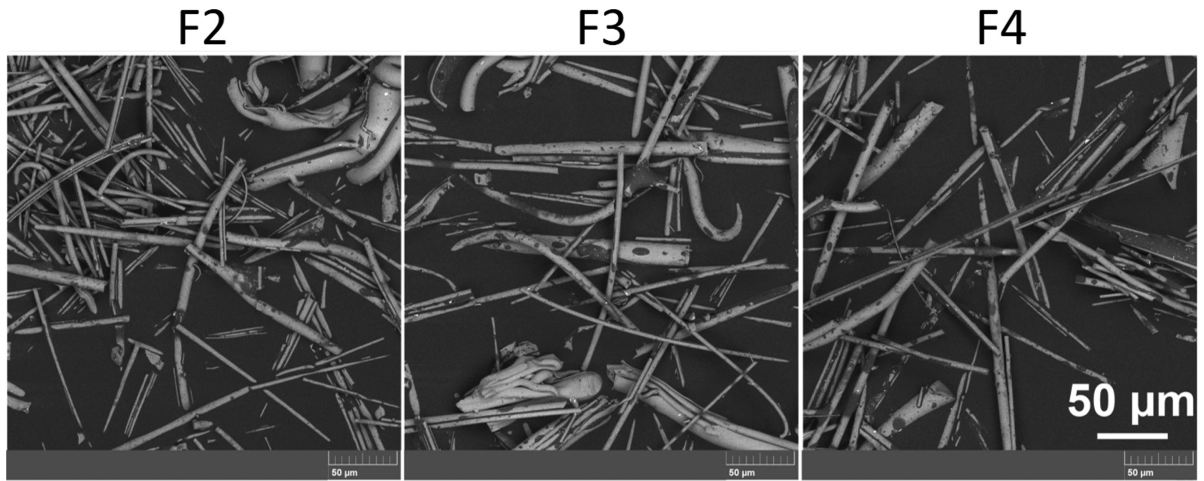

Figure 10. SEM images illustrating the inhomogeneity of the binder on samples with the different amounts of organic binder (F2-F4). Black spots on the fiber surface are PUF binder similar to that indicated in Figure 1.

The SEM images and the other results of this study suggest that the fibers dissolve regardless of the presence of binder. Stone wool fiber dissolution in synthetic lung fluid at $37^{\circ} \mathrm{C}$ is significantly faster than in solutions at similar $\mathrm{pH}$, where there are no $\mathrm{Al}$ or $\mathrm{Fe}$ complexing agents. ${ }^{44}$ Dissolution rate was 508 ng of fiber $/ \mathrm{cm}^{2} / \mathrm{h}$ in flow through experiments over $28 \mathrm{~d}$ and $770 \mathrm{ng} / \mathrm{cm}^{2} / \mathrm{h}$ for $4 \mathrm{~d}$ in the batch reactors, with similar amounts of released elements, whether the fibers were with binder or not. We could potentially expect higher dissolution rates if $\mathrm{pH}$ would be stabilized precisely at 4.5 , because of increasing dissolution rate of stone wool fiber with decreasing $\mathrm{pH}^{74}$ In our experiments, the dissolution reaction in fact took place at a slightly higher $\mathrm{pH}$ of $4.9-5.3$ caused by cation leaching from the fibers to the solution. The higher rate for the batch experiments after $4 \mathrm{~d}$ compared to rate in flow through experiments can be explained by the higher concentration of complexing agents (citrate and tartrate) compared to fiber mass and daily $\mathrm{pH}$ adjustments. For the static batch experiments, dissolution rate decreased after $4 \mathrm{~d}$ because of the concentration of free citrate and tartrate drops, while in constant flow experiments, dissolution rate remains constant because the complexing anions are constantly renewed.

\section{CONCLUSIONS}

We investigated the influence of organic material that was predominantly a phenol-urea-formaldehyde (PUF) binder (06 wt \%) on the dissolution rates of stone wool fibers in synthetic lung fluid at $37^{\circ} \mathrm{C}$ and $\mathrm{pH} 4.5$, using in vitro static batch and dynamic flow methods. The results demonstrated that there is no effect of binder on the stone wool fiber dissolution rate either in batch experiments over $4 \mathrm{~d}$ or in flow through constant composition experiments for $28 \mathrm{~d}$. The concentrations of species released from the fibers, with different amounts of binder, to the solution are similar to those without binder.

Stone wool fiber dissolution in the synthetic lung fluid at 37 ${ }^{\circ} \mathrm{C}$ and $\mathrm{pH} 4.5$ is close to congruent with slight preferential leaching of matrix cations $(\mathrm{Ca}, \mathrm{Mg})$. High dissolution rates are 
a)

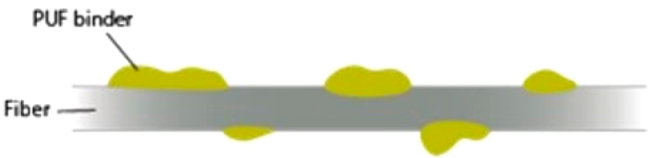

b)

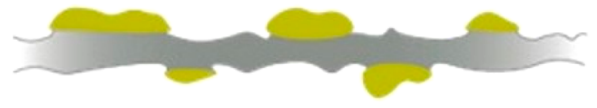

c)

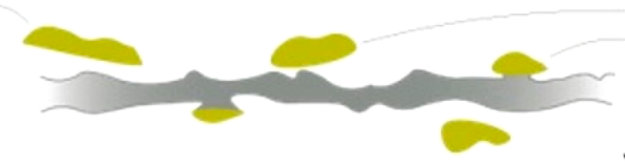

d)

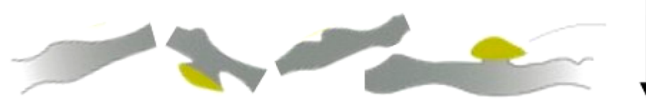

Figure 11. A schematic representation of fiber dissolution when binder is present: (a) initial fiber with binder droplets; (b) cavities formation; (c) cavities propagation and possible binder detachment; and (d) possible fiber breakage in the areas where cavities were formed. Stages (c) and (d) of the mechanism are tentative, proposed based on SEM observations.

explained by the presence of $\mathrm{Al}$ and $\mathrm{Fe}$ complexing ligands, that is, citrate and tartrate, which promote the dissolution. Morphology changes observed with SEM-EDXS showed that stone wool fiber samples with binder dissolve first in the uncovered areas by formation of cavities, which eventually undermine the binder, while fibers without binder dissolve evenly. The different modes of dissolution have no effect on the overall amount of elements released because there is enough surface area available for the reaction. Cavity propagation with time eventually leads to complete undermining of the organic material and would facilitate mechanical breakage of the fibers into shorter fragments. In summary, the in vitro results of this work demonstrate that the PUF binding agent with oil and APS at the concentrations used in the production process of a commercial stone wool product has no effect on the fiber dissolution rates in a synthetic lung fluid.

\section{ASSOCIATED CONTENT}

\section{S Supporting Information}

The Supporting Information is available free of charge on the ACS Publications website at DOI: 10.1021/acs.chemrestox.9b00179.

XPS results and fiber mass loss calculations are presented in the Supporting Information (PDF)

\section{AUTHOR INFORMATION}

\section{Corresponding Author}

*Phone: +45 465581 30. E-mail: denis.okhrimenko@ rockwool.com.

ORCID $\odot$

Denis V. Okhrimenko: 0000-0001-7279-1292

Yuanzheng Yue: 0000-0002-6048-5236

\section{Funding}

Funding was provided by ROCKWOOL International A/S. Notes

The authors declare the following competing financial interest(s): ROCKWOOL International $\mathrm{A} / \mathrm{S}$ is a stone wool manufacturer. S.H.Q.B., D.V.O., and M.S. are employed at ROCKWOOL International A/S.

\section{ACKNOWLEDGMENTS}

We thank Jesper Bøtner and Pia Nielsen for assistance with SEM-EDXS and AAS analysis and Christoph Koch, Dorte B. Johansson, Dorthe Lybye, Marianne Guldberg, and Jean Cuypers for the discussion during all stages of the project. Valuable comments from the anonymous reviewer are greatly appreciated.

\section{REFERENCES}

(1) Bernstein, D. M. (2007) Synthetic Vitreous Fibers: A Review Toxicology, Epidemiology and Regulations. Crit. Rev. Toxicol. 37, 839-886.

(2) Yue, Y., Von der Ohe, R., and Jensen, S. L. (2004) Fictive temperature, cooling, rate, and viscosity of glasses. J. Chem. Phys. 120, $8053-8059$.

(3) Kowatsch, S. (2010) Mineral Wool Insulation Binders, In Phenolic Resins: A Century of Progress (Pilato, L., Ed.) pp 209-242, Springer, Berlin, Heidelberg.

(4) Bernstein, D., Castranova, V., Donaldson, K., Fubini, B., Hadley, J., Hesterberg, T., Kane, A., Lai, D., McConnell, E. E., Muhle, H., et al. (2005) Testing of Fibrous Particles: Short-Term Assays and Strategies: Report of an ILSI Risk Science Institute Working Group. Inhalation Toxicol. 17, 497-537.

(5) Hesterberg, T. W., Anderson, R., Bernstein, D. M., Bunn, W. B., Chase, G. A., Jankousky, A. L., Marsh, G. M., and McClellan, R. O. (2012) Product stewardship and science: Safe manufacture and use of fiber glass. Regul. Toxicol. Pharmacol. 62, 257-277.

(6) Campopiano, A., Zakrzewska, A. M., Olori, A., Cannizzaro, A., Basili, F., and Ramires, D. (2012) Glass fiber exposure assessment during ceiling installation by European Standard EN 689: study of airborne fiber distribution. Atmos. Pollut. Res. 3, 192-198.

(7) Bellmann, B., Schaeffer, H. A., and Muhle, H. (2010) Impact of variations in the chemical composition of vitreous mineral fibers on biopersistence in rat lungs and consequences for regulation. Inhalation Toxicol. 22, 817-827.

(8) Andersen, A., Axten, C., Bernstein, D. M., Brochard, P., Castranova, V., Donaldson, K., Dumortier, P., Everitt, J. I., Gustavsson, P., Hesterberg, T. W., Jaurand, M. C., Kane, A. B., Marsh, G. M., Morimoto, Y., Muhle, H., Oberdörster, G., Olin, S., Savolainen, K. M., and Schneider, T. (2002) IARC Monographs on the Evaluation of Carcinogenic Risks to Humans; World Health Organization International Agency for Research on Cancer IARCPress, Lyon, France.

(9) Campopiano, A., Cannizzaro, A., Angelosanto, F., Astolfi, M. L., Ramires, D., Olori, A., Canepari, S., and Iavicoli, S. (2014) Dissolution of glass wool, rock wool and alkaline earth silicate wool: Morphological and chemical changes in fibers. Regul. Toxicol. Pharmacol. 70, 393-406.

(10) Harrison, P., Holmes, P., Bevan, R., Kamps, K., Levy, L., and Greim, H. (2015) Regulatory risk assessment approaches for synthetic mineral fibres. Regul. Toxicol. Pharmacol. 73, 425-441.

(11) Maxim, L. D., Hadley, J. G., Potter, R. M., and Niebo, R. (2006) The role of fiber durability/biopersistence of silica-based synthetic vitreous fibers and their influence on toxicology. Regul. Toxicol. Pharmacol. 46, 42-62.

(12) Searl, A., Buchanan, D., Cullen, R. T., Jones, A. D., Miller, B. G., and Soutar, C. A. (1999) Biopersistence and durability of nine mineral fibre types in rat lungs over 12 months. Ann. Occup. Hyg. 43, 143153. 
(13) Kamstrup, O., Davis, J. M. G., Ellehauge, A., and Guldberg, M. (1998) The Biopersistence and Pathogenicity of Man-made Vitreous Fibres after Short- and Long-term Inhaltion. Ann. Occup. Hyg. 42, 191-199.

(14) Hesterberg, T. W., Chase, G., Axten, C., Miller, W. C., Musselman, R. P., Kamstrup, O., Hadley, J., Morscheidt, C., Bernstein, D. M., and Thevenaz, P. (1998) Biopersistence of Synthetic Vitreous Fibers and Amosite Asbestos in the Rat Lung Following Inhalation. Toxicol. Appl. Pharmacol. 151, 262-275.

(15) Hesterberg, T. W., Miiller, W. C., Musselman, R. P., Kamstrup, O., Hamilton, R. D., and Thevenaz, P. (1996) Biopersistence of ManMade Vitreous Fibers and Crocidolite Asbestos in the Rat Lung Following Inhalation. Toxicol. Sci. 29, 267-279.

(16) Hesterberg, T. W., Miiller, W. C., Mast, R., McConnell, E. E., Bernstein, D. M., and Anderson, R. (1994) Relationship between lung biopersistence and biological effects of man-made vitreous fibers after chronic inhalation in rats. Environ. Health Perspect. 102, 133.

(17) Eastes, W., Baron, P. A., Baier, R. E., Guldberg, M., and Potter, R. (2007) Do vitreous fibers break in the lung? Inhalation Toxicol. 19, $311-315$.

(18) Guldberg, M., Jensen, S. L., Knudsen, T., Steenberg, T., and Kamstrup, O. (2002) High-Alumina Low-Silica HT Stone Wool Fibers: A Chemical Compositional Range with High Biosolubility. Regul. Toxicol. Pharmacol. 35, 217-226.

(19) Donaldson, K., Tran, C. L., and MacNee, W. (2002) Deposition and effects of fine and ultrafine particles in the respiratory tract. Eur. Respir. Monogr. 7, 77-92.

(20) Donaldson, K., and Tran, C. L. (2004) An introduction to the short-term toxicology of respirable industrial fibres. Mutat. Res., Fundam. Mol. Mech. Mutagen. 553, 5-9.

(21) Ng, A. W., Bidani, A., and Heming, T. A. (2004) Innate host defense of the lung: effects of lung-lining fluid pH. Lung 182, 297317.

(22) Etherington, D., Pugh, D., and Silver, I. (1981) Collagen degradation in an experimental inflammatory lesion: studies on the role of the macrophage. Acta Biol. Med. Ger. 40, 1625-1636.

(23) Oberdörster, G. (1991) Deposition, elimination and effects of fibres in the respiratory tract of humans and animals. VDI-Ber. 853, $13-37$.

(24) Eastes, W., Potter, R. M., and Hadley, J. G. (2000) Estimating In Vitro Glass Fiber Dissolution Rate from Composition. Inhalation Toxicol. 12, 269-280.

(25) Guldberg, M., de Meringo, A., Kamstrup, O., Furtak, H., and Rossiter, C. (2000) The development of glass and stone wool compositions with increased biosolubility. Regul. Toxicol. Pharmacol. $32,184-189$.

(26) Knudsen, T., and Guldberg, M. (2005) In vitro dissolution rate of mineral fibres at $\mathrm{pH} 4.5$ and 7. 4- A new mathematical tool to evaluate the dependency on composition. Glass Sci. Technol. 78, 132138.

(27) Zoitos, B. K., De Meringo, A., Rouyer, E., Bauer, S. T. J., Law, B., Boymel, P. M., Olson, J. R., Christensen, V. R., Guldberg, M., and Koenig, A. R. (1997) In vitro measurement of fiber dissolution rate relevant to biopersistence at neutral $\mathrm{pH}$ : An interlaboratory round robin. Inhalation Toxicol. 9, 525-540.

(28) Guldberg, M., Christensen, V. R., Perander, M., Zoitos, B., Koenig, A. R., and Sebastian, K. (1998) Measurement of In-Vitro Fibre Dissolution Rate at Acidic pH. Ann. Occup. Hyg. 42, 233-243.

(29) Luoto, K., Holopainen, M., Kangas, J., Kalliokoski, P., and Savolainen, K. (1998) Dissolution of Short and Long Rockwool and Glasswool Fibers by Macrophages in Flowthrough Cell Culture. Environ. Res. 78, 25-37.

(30) Luoto, K., Holopainen, M., and Savolainen, K. (1995) Durability of man-made vitreous fibres as assessed by dissolution of silicon, iron and aluminium in rat alveolar macrophages. Ann. Occup. Hyg. 39, 855-867.

(31) Luoto, K., Holopainen, M., Karppinen, K., Perander, M., and Savolainen, K. (1994) Dissolution of man-made vitreous fibers in rat alveolar macrophage culture and Gamble's saline solution: influence of different media and chemical composition of the fibers. Environ. Health Perspect. 102, 103.

(32) Luoto, K., Holopainen, M., Kangas, J., Kalliokoski, P., and Savolainen, K. (1995) The effect of fiber length on the dissolution by macrophages of rockwool and glasswool fibers. Environ. Res. 70, 5161.

(33) Nguea, H. D., de Reydellet, A., Lehuédé, P., de Méringo, A., Robé, A., Le Faou, A., and Rihn, B. H. (2008) A new in vitro cellular system for the analysis of mineral fiber biopersistence. Arch. Toxicol. 82, 435-443.

(34) Kumar, A., Terakosolphan, W., Hassoun, M., Vandera, K.-K., Novicky, A., Harvey, R., Royall, P. G., Bicer, E. M., Eriksson, J., Edwards, K., et al. (2017) A Biocompatible Synthetic Lung Fluid Based on Human Respiratory Tract Lining Fluid Composition. Pharm. Res. 34, 2454-2465.

(35) Colombo, C., Monhemius, A. J., and Plant, J. A. (2008) Platinum, palladium and rhodium release from vehicle exhaust catalysts and road dust exposed to simulated lung fluids. Ecotoxicol. Environ. Saf. 71, 722-730.

(36) Boisa, N., Elom, N., Dean, J. R., Deary, M. E., Bird, G., and Entwistle, J. A. (2014) Development and application of an inhalation bioaccessibility method (IBM) for lead in the PM10 size fraction of soil. Environ. Int. 70, 132-142.

(37) Scholze, H., and Conradt, R. (1987) An in vitro study of the chemical durability of siliceous fibres. Ann. Occup. Hyg. 31, 683-692.

(38) Sebastian, K., Fellman, J., Potter, R., Bauer, J., Searl, A., Meringo, A. d., Maquin, B., Reydellet, A. d., Jubb, G., and Moore, M. (2002) EURIMA test guideline: In-vitro acellular dissolution of manmade vitreous silicate fibres. Glass Sci. Technol. 75, 263-270.

(39) Kreyling, W. G. (1992) Intracellular particle dissolution in alveolar macrophages. Environ. Health Perspect. 97, 121-126.

(40) Kanapilly, G. M. (1977) Alveolar Microenvironment and Its Relationship to the Retention and Transport Into Blood of Aerosols Deposited in the Alveoli. Health Phys. 32, 89-100.

(41) Pettibone, J. M., Adamcakova-Dodd, A., Thorne, P. S., O'Shaughnessy, P. T., Weydert, J. A., and Grassian, V. H. (2008) Inflammatory response of mice following inhalation exposure to iron and copper nanoparticles. Nanotoxicology 2, 189-204.

(42) Kalkwarf, D. R. (1983) Dissolution rates of uranium compounds in simulated lung fluid. Sci. Total Environ. 28, 405-414.

(43) Charrier, J. G., McFall, A. S., Richards-Henderson, N. K., and Anastasio, C. (2014) Hydrogen peroxide formation in a surrogate lung fluid by transition metals and quinones present in particulate matter. Environ. Sci. Technol. 48, 7010-7017.

(44) Steenberg, T., Hjenner, H. K., Jensen, S. L., Guldberg, M., and Knudsen, T. (2001) Dissolution behaviour of biosoluble HT stone wool fibres. Glass Sci. Technol. 74, 97-105.

(45) Welch, S. A., and Ullman, W. J. (1996) Feldspar dissolution in acidic and organic solutions: Compositional and $\mathrm{pH}$ dependence of dissolution rate. Geochim. Cosmochim. Acta 60, 2939-2948.

(46) Stumm, W., and Furrer, G. The dissolution of oxides and silicates (1987) Examples of surface-coordination-controlled kinetics. Aquatic Surface Chemistry, Wiley-Interscience, Hoboken, NJ.

(47) Pelfrêne, A., Cave, M. R., Wragg, J., and Douay, F. (2017) In Vitro Investigations of Human Bioaccessibility from Reference Materials Using Simulated Lung Fluids. Int. J. Environ. Res. Public Health 14, 112.

(48) Christensen, V. R., Jensen, S. L., Guldberg, M., and Kamstrup, O. (1994) Effect of chemical composition of man-made vitreous fibers on the rate of dissolution in vitro at different pHs. Environ. Health Perspect. 102, 83-86.

(49) Baan, R. A., and Grosse, Y. (2004) Man-made mineral (vitreous) fibres: evaluations of cancer hazards by the IARC Monographs Programme. Mutat. Res., Fundam. Mol. Mech. Mutagen. $553,43-58$

(50) Bauer, J. (1998) Interaction of glass fiber with physiological fluids: the role of surface. Proceedings of the 18th International Congress on Glass, San Francisco, California, July 5-10, 1998, American Ceramic Society, Westerville, OH, pp 1-10. 
(51) Potter, R. M., and Olang, N. (2013) The effect of a new formaldehyde-free binder on the dissolution rate of glass wool fibre in physiological saline solution. Part. Fibre Toxicol. 10, 13.

(52) Mattson, S. M. (1995) Factors affecting fiber dissolution-invitro experiments. Proceedings of the 17th International Congress on Glass, Beijing, China, October 9-14, 1995, American Ceramic Society, Westerville, OH, pp 368-373.

(53) Wohlleben, W., Waindok, H., Daumann, B., Werle, K., Drum, M., and Egenolf, H. (2017) Composition, respirable fraction and dissolution rate of 24 stone wool MMVF with their Binder. Part. Fibre Toxicol. 14, 29.

(54) De Meringo, A., Morscheidt, C., Thélohan, S., and Tiesler, H. (1994) In vitro assessment of biodurability: acellular systems. Environ. Health Perspect. 102, 47.

(55) Yue, Y., Korsgaard, M., Kirkegaard, L. F., and Heide, G. (2009) Formation of a Nanocrystalline Layer on the Surface of Stone Wool Fibers. J. Am. Ceram. Soc. 92, 62-67.

(56) Christensen, V. R., Eastes, W., Hamilton, R. D., and Struss, A. W. (1993) Fiber Diameter Distributions in Typical MMVF Wool Insulation Products. Am. Ind. Hyg. Assoc. J. 54, 232-238.

(57) Koenig, A. R., Hamilton, R. D., Laskowski, T. E., Olson, J. R., Gordon, J. F., Christensen, V. R., and Byers, C. D. (1993) Fiber diameter measurement of bulk man-made vitreous fiber. Anal. Chim. Acta 280, 289-298.

(58) Conradt, R. (2017) Report on the EURIMA guideline in vitro acellular dissolution of man-made vitreous fibres. RWTH Aachen University, unpublished work.

(59) Kirkegaard, L. F., Korsgaard, M., and Yue, Y. (2005) Redox behaviour of high iron-containing glass fibres during heat-treatment under atmospheric conditions. Phys. Chem. Glasses: Eur. J. Glass Sci. Technol., Part B 78, 1-6.

(60) Grambow, B. (1984) A General Rate Equation for Nuclear Waste Glass Corrosion. MRS Proceedings 44, 15.

(61) Helebrant, A., and Pekárková, I. (1996) Kinetics of glass corrosion in acid solutions. Berichte der Bunsengesellschaft für physikalische Chemie 100, 1519-1522.

(62) Gunnarsson, I., and Arnórsson, S. (2000) Amorphous silica solubility and the thermodynamic properties of $\mathrm{H}_{4} \mathrm{SiO}^{\circ} 4$ in the range of $0^{\circ}$ to $350^{\circ} \mathrm{C}$ at Psat. Geochim. Cosmochim. Acta 64, 2295-2307.

(63) Grambow, B., and Müller, R. (2001) First-order dissolution rate law and the role of surface layers in glass performance assessment. J. Nucl. Mater. 298, 112-124.

(64) Gregor, J., and Powell, H. (1986) Aluminum(III)-Citrate Complexes: a Potentiometric and 13C N.M.R.-Study. Aust. J. Chem. 39, $1851-1864$

(65) Öhman, L.-O., and Sjöberg, S. (1983) Equilibrium and structural studies of silicon(IV) and aluminium(III) in aqueous solution. Part 9. A potentiometric study of mono- and poly-nuclear aluminium(III) citrates. J. Chem. Soc., Dalton Trans., 2513-2517.

(66) Timberlake, C. (1964) 975. Iron-malate and iron-citrate complexes. J. Chem. Soc. 0, 5078-5085.

(67) Chen, Y., Liu, Z., Wang, Z., Xue, M., Zhu, X., and Tao, T. (2011) Photodegradation of propranolol by $\mathrm{Fe}(\mathrm{III})$-citrate complexes: Kinetics, mechanism and effect of environmental media. J. Hazard. Mater. 194, 202-208.

(68) Desroches, S., Daydé, S., and Berthon, G. (2000) Aluminum speciation studies in biological fluids: Part 6. Quantitative investigation of aluminum(III)-tartrate complex equilibria and their potential implications for aluminum metabolism and toxicity. J. Inorg. Biochem. 81, 301-312.

(69) Timberlake, C. (1964) 242. Iron-tartrate complexes. J. Chem. Soc. 0, 1229-1240.

(70) Wang, L., Zhang, C., Wu, F., and Deng, N. (2006) Photoproduction and determination of hydroxyl radicals in aqueous solutions of $\mathrm{Fe}(\mathrm{III})$-tartrate complexes: a quantitative assessment. J. Coord. Chem. 59, 803-813.

(71) Gislason, S. R., and Oelkers, E. H. (2003) Mechanism, rates, and consequences of basaltic glass dissolution: II. An experimental study of the dissolution rates of basaltic glass as a function of $\mathrm{pH}$ and temperature. Geochim. Cosmochim. Acta 67, 3817-3832.

(72) Oelkers, E. H., and Gislason, S. R. (2001) The mechanism, rates and consequences of basaltic glass dissolution: I. An experimental study of the dissolution rates of basaltic glass as a function of aqueous, $\mathrm{Al}, \mathrm{Si}$ and oxalic acid concentration at $25 \mathrm{C}$ and $\mathrm{pH}=3$ and 11. Geochim. Cosmochim. Acta 65, 3671-3681.

(73) Okhrimenko, D. V., Thomsen, A. B., Ceccato, M., Johansson, D. B., Lybye, D., Bechgaard, K., Tougaard, S., and Stipp, S. L. S. (2018) Impact of curing time on ageing and degradation of phenolurea-formaldehyde binder. Polym. Degrad. Stab. 152, 86-94.

(74) Guldberg, M., Madsen, A. L., Sebastian, K., Fellman, J., Potter, R., Corning, O., Bauer, J., Manville, J., Searl, A., and Maquin, B. (2003) In vitro dissolution of vitreous silicate fibres according to EURIMA test guideline: Results of two Round Robins. Glass Sci. Technol. 76, 199-205. 